\title{
Áreas protegidas e sociobiodiversidade no
} Semiárido brasileiro

Protected areas and sociobiodiversity in the Brazilian semi-arid region

Lara Erendira Almeida de Andrade e Marcelino Soyinka Santos Dantas

\section{(2) OpenEdition \\ 12 Journals \\ Edição electrónica \\ URL: https://journals.openedition.org/aa/4938 \\ DOI: $10.4000 /$ aa. 4938 \\ ISSN: 2357-738X \\ Editora \\ Programa de Pós-Graduação em Antropologia Social (UnB)}

\section{Edição impressa}

Paginação: 69-96

ISSN: 0102-4302

Refêrencia eletrónica

Lara Erendira Almeida de Andrade e Marcelino Soyinka Santos Dantas, «Áreas protegidas e sociobiodiversidade no Semiárido brasileiro», Anuário Antropológico [Online], v.45 n. 1 | 2020, posto online no dia 27 janeiro 2020, consultado o 22 julho 2022. URL: http://journals.openedition.org/aa/ 4938 ; DOI: https://doi.org/10.4000/aa.4938

\section{(c) $)(9)$}

Creative Commons - Atribuição-NãoComercial-SemDerivações 4.0 Internacional - CC BY-NC-ND 4.0 https://creativecommons.org/licenses/by-nc-nd/4.0/ 


\title{
Áreas protegidas e sociobiodiversidade no Semiárido brasileiro
}

\author{
Protected areas and sociobiodiversity in the Brazilian semi-arid region \\ DOI: https://doi.org/10.400๑/aa.4938
}

\begin{abstract}
Lara Erendira Almeida de Andrade • Doutoranda - PPGA/UFPE
Doutoranda no PPGA/UFPE (bolsista Capes). Ao longo dos últimos anos desenvolveu pesquisa na temática territorial e dos conhecimentos indígenas no semiárido brasileiro. Tem experiência na demarcação de Terras Indígenas e Quilombolas na região e atua no campo da gestão territorial e ambiental nestes contextos.
\end{abstract}

\footnotetext{
Marcelino Soyinka Santos Dantas • Indigenista especializado - Funai

Biólogo e mestre em Ecologia pelo Instituto Nacional de Pesquisas da Amazônia-INPA. Atua no fortalecimento e promoção dos direitos indígenas, com apoio a processos de gestão territorial e ambiental junto a diversas etnias na região da Amazônia legal e da Caatinga. No presente atua como Indigenista Especializado na Fundação Nacional do Índio-Funai
}

A ideia de áreas protegidas para a conservação, apesar dos avanços nas últimas décadas para incluir a sociodiversidade, ainda possui forte influência do chamado "mito da natureza intocada", reflexo da pretensa dicotomia natureza/cultura à qual também se associa a imagem dos indígenas. Esta noção reflete-se nas ações do Estado, que enfatiza políticas de proteção naquelas áreas mais próximas de seu pretenso estágio "prístino". Não por acaso, a maioria das áreas protegidas situa-se na Amazônia, ícone desta "natureza intocada" e dos índios "puros". Um exemplo é a efetivação dos direitos territoriais indígenas: $93 \%$ das Terras Indígenas situam-se na Amazônia Legal, apesar de $61 \%$ dos indígenas viverem em outras regiões. O Nordeste é exemplar neste sentido: a região convive com a escassez de iniciativas de apoio à conservação ou aos direitos indígenas. Não é de estranhar que a ela esteja associado o imaginário da seca, pobreza e do "índio misturado". Neste trabalho propomos refletir sobre as práticas dos povos indígenas de convivência com o ambiente vis- $a$-vis à lógica de intervenções do Estado para conservação da biodiversidade. Partimos da experiência em processos de Gestão Territorial e Ambiental com os Xokó, Pankararu e Kapinawá. Áreas protegidas. Terras indígenas. Indígenas no Semiárido brasileiro.
The idea of protected areas for conservation, despite advances in the last decades to include sociodiversity, still has a strong influence of the so-called "wilderness myth", reflecting the so-called nature/culture dichotomy, to which the indigenous image is also related. This notion is reflected in the State actions, which emphasizes protection policies on those areas closer to its pretended "pristine". Thus, it is no coincidence that most of the current protected areas are in the Amazonian biome, an icon of this "untouched wilderness" and of the so called "pure" Indians. That situation is exemplified by observing the enforcement of indigenous land rights: $93 \%$ of regularized Indigenous Lands are in the Amazon, although $61 \%$ of indigenous people live outside the North of Brazil. The Northeast region is exemplary in this sense: the region coexists with the scarcity of state and non-state initiatives to support conservation or the rights of the indigenous populations that live there. It is not surprising that it is associated with the imagery of drought, poverty and the "integrated" indians. In this work we propose to reflect on the practices of indigenous peoples living with the environment vis a vis the State logic of interventions for the conservation of biodiversity. To do so, we start from our experience in Indigenous Land Territorial and Environmental Management processes with the Xokó, Pankararu and Kapinawá. It is analyzed like case more specific the one of this last town, in whose territory there is a unit of conservation of integral protection superimposed.

Indigenous territories. Territorial and environmental management. Indigenous peoples in the Northeast. 


\section{Introdução}

A ideia de áreas protegidas para a conservação da natureza, apesar dos avanços nas últimas décadas no sentido de incluir sociodiversidade, ainda possui forte influência do chamado "mito da natureza intocada" (Diegues, 2002; Gomez-Pompa; Kaus, 1992), resultado de uma pretensa dicotomia natureza/cultura ainda fortemente presente nos meios preservacionistas. Não obstante, a criação de espaços com restrições de uso ou acesso diversos por meio das chamadas "áreas protegidas" tem sido a principal estratégia utilizada para conservação da biodiversidade ao redor do mundo (Dudley, 2008; Bensunsan, 2014).

Esta situação pode ser considerada consequência da própria trajetória histórica de tais campos de atuação: apesar do uso corrente principalmente nos meios conservacionistas e socioambientalistas (e incorporados às práticas dos Estados Nacionais), o histórico desta prática remonta à Antiguidade.

A partir da percepção das populações europeias como agentes de transformações significativas e deletérias na paisagem, os primeiros espaços protegidos com esta função surgiram inicialmente com o intuito de reservar parcelas do território para preservar paisagens "icônicas", próximas daquilo que se imaginava como condição "prístina" da natureza, percebida para essas populações como ausência total do ser humano. Com o decorrer do tempo (principalmente após a Revolução Industrial), o conceito foi modificado para focar na perspectiva crescente de conservação da biodiversidade e, em seguida, para incluir também o papel de algumas sociedades e suas distintas relações com o ambiente na conservação daquilo que se convencionou chamar de "meio natural" (Bensusan, 2014; Diegues, 2002).

Em que pesem os questionamentos crescentes sobre sua adequação às condições do chamado "ambiente natural", resquícios deste "mito da natureza intocada" ainda possuem, nos tempos atuais, influência marcante na forma como são elaboradas e executadas as políticas públicas voltadas à proteção ambiental no Brasil. Observa-se sua influência direta nas ações do Estado para conservação da chamada sociobiodiversidade, que historicamente tem enfatizado seus esforços de proteção nas áreas em situação mais próxima de seu pretenso estado "prístino", especialmente nas regiões que contam com vegetações mais exuberantes.

Assim, não por acaso a maior parte das áreas protegidas atuais no Brasil situa-se no bioma amazônico, ícone maior desta idealizada "natureza intocada". Efeito análogo pode ser constatado, por exemplo, na efetivação dos direitos territoriais indígenas 2 : observa-se que $98 \%$ da área demarcada como Terra Indígena (TI) no país se encontram na Amazônia Legal ${ }^{3}$ (Funai, 2019), apesar de mais da metade (53\%) da população indígena viver em outras regiões (IBGE, 2010).

A Região Nordeste é exemplar nesse sentido, particularmente o Semiárido: comparada a outras áreas do país, a região convive com a escassez de iniciativas estatais e não estatais de apoio aos direitos das populações indígenas que aí habitam, bem como são parcas as iniciativas de apoio à conservação ambiental, em contraste com as áreas da floresta amazônica. Não é de estranhar que a ela esteja associado o imaginário da seca, da pobreza e do "índio misturado".

O que estamos aqui vagamente denominando de "imaginário" não fica apenas
1 Em que pese o fato de haver um corpo sólido e crescente de evidências que apontam justamente na direção oposta, ou seja, que parte significativa da diversidade amazônica é fruto (e não apesar) da ação humana das sociedades que ali viveram em tempos pretéritos (Clement et al., 2015).

2 O papel das Terras Indígenas e Quilombolas para a conservação da biodiversidade foi reconhecido legalmente no Plano Estratégico nacional de Áreas Protegidas - PNAP, instituído através do Decreto 5.758/2.006. O Decreto inclui entre suas diretrizes "assegurar os direitos territoriais das comunidades quilombolas e dos povos indígenas como instrumento para conservação de biodiversidade", entre outros aspectos. Desta forma, considera-se que tais áreas consistem em áreas protegidas, tal qual conceituado pela IUCN (Dudley, 2008).

3 De acordo com definição do IBGE (2014), "a Amazônia Legal corresponde à área de atuação da Superintendência de Desenvolvimento da Amazônia - SUDAM delimitada no Art. $2^{\circ}$ da Lei Complementar n. 124, de 03.01.2007. A região é composta pelos Estados do Acre, Amapá, Amazonas, Pará, Rondônia, Roraima, Tocantins e Mato Grosso, bem como pelos Municípios do Estado do Maranhão situados ao oeste do Meridiano $44^{\circ}$. Possui uma superfície aproximada de 5 $217423 \mathrm{~km}^{2}$, correspondente a cerca de $61 \%$ do território brasileiro". 
no campo das ideias, mas tem consequências práticas: por exemplo, na elaboração e execução de políticas públicas voltadas à temática socioambiental na região.

Observa-se que enquanto na região amazônica as políticas públicas e iniciativas que apoiam ações e vinculam questões ambientais às indigenistas começaram a experimentar um boom no fim da década de 1980 a partir da Constituinte e da Eco $92^{4}$ (Ramos, 2014), no Nordeste brasileiro as políticas públicas neste sentido foram implementadas apenas marginalmente.

Mesmo casos mais recentes como na concepção e implementação da Política Nacional de Gestão Territorial e Ambiental de Terras Indígenas - PNGATI, implementada pelo Decreto $n^{0} 7.747 / 2012$, ações só foram efetivamente direcionadas para a região posteriormente e muito em função de reivindicações e mobilização política do movimento indígena - em particular da Articulação dos Povos Indígenas no Nordeste, Minas Gerais e Espírito Santo (APOINME) ${ }^{5}$.

Neste trabalho propomos refletir sobre o papel subestimado das Terras Indígenas (TIs) enquanto áreas protegidas responsáveis por conservação da biodiversidade no contexto do Semiárido brasileiro, papel atribuído e enfatizado frequentemente ao tratar das TIs amazônicas e do cerrado. $\mathrm{O}$ argumento central deste texto é que a garantia dos direitos territoriais indígenas através da demarcação das Terras Indígenas, mesmo em contextos adversos de áreas diminutas como na região trabalhada, ainda assume papel relevante e imprescindível para proteção da chamada biodiversidade, em especial em biomas negligenciados, como a região da Caatinga.

Essa constatação do papel das populações indígenas na gestão e manutenção das áreas protegidas não é algo novo (ver, dentre outros, a relevante coletânea produzida por Ricardo, 2004); é reconhecido inclusive por organismos internacionais e instrumentos normativos nacionais, a exemplo da União Internacional para Conservação da Natureza (Internacional Union for Conservation of Nature - IUCN) e o Plano Estratégico Nacional de Áreas Protegidas - PNAP. A IUCN define "área protegida" como o "espaço geográfico claramente definido, reconhecido, com objetivo específico e gerido por meios eficazes, sejam jurídicos ou de outra natureza, para alcançar a conservação da natureza no longo prazo, com serviços ecossistêmicos e valores culturais associados" (Dudley, 2008). Na legislação brasileira, tais espaços são descritos no PNAP e incluem as Unidades de Conservação (UCs) e "demais áreas protegidas na conservação da diversidade biológica e sociocultural", compreendendo também as Terras Indígenas e Quilombolas (Decreto 5.758/2016).

Entretanto, quando se trata do semiárido brasileiro, esse é um debate ainda embrionário. As razões desta situação buscaremos refletir ao longo do texto. Desenvolvemos esta reflexão a partir de nossa experiência no apoio a processos de Gestão Territorial e Ambiental de Terras Indígenas com os povos indígenas Xokó (SE), Pankararu e Kapinawá (PE). As ações foram realizadas entre os anos de 2014 e 2017 junto à Associação Nacional de Ação Indigenista (Anaí) ${ }^{6}$ e do Centro de Cultura Professor Luiz Freire (CCLF $)^{7}$. Em ambas compusemos equipes multidisciplinares que promoveram diagnósticos participativos focados no mapeamento territorial voltado para a elaboração de Plano de Gestão Territorial e Ambiental (PGTA) das TIs mencionadas. Vale mencionar que este texto é nosso primeiro exercício
4 Iniciativas como o Projeto Integrado de Proteção às Populações e Terras Indígenas da Amazônia Legal - PPTAL (1996-2008) e o projeto Áreas Protegidas da Amazônia - ARPA (2002-) são dois exemplos de iniciativas de caráter regional que alcançaram amplos resultados durante este período na implementação de áreas protegidas através de apoio à execução de políticas públicas na Amazônia brasileira.

5 Para um relato do processo de participação indígena na construção da PNGATI, ver APIB (2016).

6 No primeiro caso, a Anaí foi indicada pela Articulação dos Povos e Organizações Indígenas do Nordeste, Minas Gerais e Espírito Santo (APOINME) para o desenvolvimento do projeto junto das comunidades das Terras Indígenas (TIs) Caiçara/ Ilha de São Pedro (Sergipe) e Entre Serras (Pernambuco), que estava inserido nas ações do Projeto Gestão Ambiental e Territorial Indígena (Gati). A equipe técnica da Anaí foi composta por: Alexandre Santos Pankararu - Cineasta indígena; Ana Paula Ferreira de Lima Gestora do projeto; Avelar Araújo dos Santos Júnior - Geógrafo; Cristiane Gomes Julião - Pesquisadora indígena; Lara Erendira Andrade - Antropóloga; Marcelino Soyinka Santos Dantas - Biólogo/Indigenista; Maurice Seiji Tomioka Nilsson - Geógrafo. A supervisão foi feita por: Isabel Fróes Modercin - Bióloga/Antropóloga - Projeto GATI; José Augusto Laranjeiras Sampaio - Antropólogo - Anaí. 7 Já a atuação do CCLF junto aos Kapinawá foi realizada via edital vinculado ao projeto de Implementação da Política Nacional de Gestão Territorial e Ambiental de Terras Indígenas no contexto do cerrado e caatinga. A equipe técnica do CCLF foi composta por: Ana Paula Ferreira de Lima (Gestora 
de análise regional, tendo como ponto de partida os casos locais mencionados.

$\mathrm{O}$ texto está dividido em quatro seções. Inicialmente optamos por refletir as principais categorias do artigo, sejam elas: "índio misturado", sertão, semiárido e caatinga. Buscamos apresentar aspectos históricos, sociais e ambientais que estão na conformação de cada uma delas. Nas duas seções seguintes tratamos de dados sobre as unidades de conservação da natureza, bem como acerca de presença indígena no Semiárido brasileiro. Por fim, apresentamos os casos locais que nos levam a argumentar que as TIs são áreas protegidas da sociobiodiversidade na região em questão.

\section{Sublinhando categorias: "índio misturado", sertão, semiárido e a caatinga}

Para refletir sobre o que chamamos de sociobiodiversidade, a partir da Região Nordeste, que nos é de interesse, achamos importante considerá-las em seus aspectos históricos, sociais e ambientais. Cada uma dessas ideias gostaríamos de relacionar às categorias que enumeram este tópico do texto. Esta distinção é apenas um artifício retórico explicativo (visto que todas as categorias se perpassam) que utilizamos para não perder de vista quão ampla é a realidade da vida socioambiental.

Assim, sublinhamos a ideia de sertão - e o imaginário a ele atribuído - como uma noção histórica, que se constrói a partir do século XVII com o avanço colonial para tal região. Em seguida, relacionamos a ideia de semiárido como uma noção social para apontar que essa região - que se construiu historicamente como sertão hoje é englobada por uma categoria de Estado, que identifica parte do seu território nacional a partir de critérios climáticos e políticos, o Semiárido brasileiro. Por fim, a caatinga como uma noção ambiental, pois é um bioma que reúne uma série de características que influenciam diretamente sobre as condições históricas e sociais.

\section{Os índios e o sertão}

do projeto); José Augusto Laranjeiras Sampaio (Supervisor técnico/Colaborador Anaí); Lara Erendira Almeida de Andrade (Coordenadora e Antropóloga); Marcelino Soyinka Santos Dantas (Ecólogo).

Ambos foram desenvolvidos no âmbito inicial de implementação da PNGATI. Tais experiências foram publicadas nos livros: 0 tempo e a terra: mapeamento do Território Kapinawá (ANDRADE; DANTAS, 2017); Etnomapeamento da Terra Indígena Entre Serras Pankararu (ANDRADE; DANTAS; NILSSON, 2016) e Etnomapeamento da Terra Indígena Caiçara/Ilha de São Pedro do povo Xokó (SANTOS JÚNIOR; DANTAS; NILSSON, 2016)

Para compreender este cenário na contemporaneidade, é importante considerar que a Região Nordeste do Brasil é a frente mais antiga de avanço colonial no país. No chamado sertão nordestino, a expansão se deu de forma mais sistemática a partir do século XVII, quando os colonizadores se inseriram em busca de minério, particularmente do salitre para a produção da pólvora; bem como pelos curraleiros, na busca de grandes porções de terras para a criação do gado, seja para o abastecimento das referidas minas, ou para o provimento mais generalizado da colônia (Pompa, 2001). A pecuária bovina é ainda hoje uma das principais atividades econômicas da região.

É nesse processo de expansão colonial que começa a se construir a ideia de sertão. Interessada em compreender a construção da colônia no sertão, a antropóloga Cristina Pompa nos lembra que é preciso considerá-la como uma categoria que se 
cria a partir do imaginário português: do sertão como oposição ao litoral e, por conseguinte, tapuia vs tupi ao tratar dos povos indigenas que habitavam esse espaço.

Vale esclarecer, desde o início, que mais do que delimitação geográfica, o sertão é um espaço físico e também um lugar cultural, que vem sendo construído aos poucos pelos agentes e, principalmente, pelos relatos coloniais. Seguindo o raciocínio de Certeau, poder-se-ia pensar que os agentes sociais (índios, missionários, colonos, militares) constroem o espaço móvel do sertão, levando cada vez mais longe, junto com as boiadas, as missões, os descimentos e as guerras, a fronteira entre o "eu" civilizado e o "outro" bárbaro. Paralelamente, os relatos, pelo menos desde Gabriel Soares de Sousa, preocupam-se em transformar o espaço vivido em lugar cultural, cristalizando o sertão enquanto conceito, ao mesmo tempo que ele se dilui enquanto espaço. Assim como os "Tapuia” que o habitam, o sertão é móvel e feroz, constituindo um desafio à colônia.

Mais do que a etimologia da palavra "sertão", seu campo semântico de aplicação deveria ser procurado no imaginário português, já que a ideia de sertão como "interior" ou como espaço que se opõe ao litoral, já aparece na Carta de Caminha, onde, vista pelo sertão, a nova terra aparece muito grande (Pompa, 2001, p. 199, grifos nossos).

Este espaço vivido, que vai se transformado em um lugar cultural, e cristalizado em uma categoria de lugar, começa então a carregar consigo uma série de atributos, entre os quais: espaço que se opõe ao litoral, muito grande, móvel, interior, bárbaro e feroz. É interessante perceber que os atributos de espaço são os mesmos utilizados para adjetivar os indígenas que nele viviam, e vice-versa.

Tal aspecto também é discutido em artigo pioneiro sobre os indígenas nesta região, produzido pelos/as antropólogos/as vinculados ao PINEB (Programa de Pesquisas sobre Povos Indígenas do Nordeste Brasileiro): "Os Povos Indígenas no Nordeste Brasileiro - um esboço histórico” (Dantas; Sampaio; Carvalho, 1992). Nele, os/as autores/as já sublinhavam os aspectos apresentados no parágrafo anterior, com ênfase nos adjetivos que tal região e os índios vão ganhando ao longo do avanço da fronteira da colônia. No caso deste artigo, as/os autoras/es estão preocupadas/os em traçar a construção sociológica do estigma que foi sendo criado acerca dos indígenas. Optamos por trazer uma grande citação a seguir para apresentar uma série de outras adjetivações, entre as quais: marginal, residual, aculturado, inimigo e misturado.

É a partir dos estudos destes autores do Pineb que começa a se delinear, ainda nos anos de 1970/80, a ideia desta região como um "conjunto étnico e histórico", o Nordeste indígena: "o dos diversos povos adaptativamente relacionados à caatinga $\mathrm{e}$ historicamente associados às frentes pastoris e ao padrão missionário dos séculos XVII e XVIII” (Dantas; Sampaio; Carvalho, 1992, p. 433). 
Chamamos atenção para este aspecto, porque ele nos parece útil à compreensão da história dos povos indígenas que viviam e vivem no Nordeste e que, a partir da uma grande diversidade étnica, lograram se constituir, mediante um prolongado contato com frentes de expansão determinadas, em uma unidade histórica e etnológica tornada possível sob o indelével signo da marginalidade.

"Marginal" é, aliás, justamente a categoria escolhida por Steward (1946) para classificar dicotomicamente todos os povos sul-americanos não relacionados à floresta tropical, caso típico de todos os povos do Nordeste se excluídos os Tupi costeiros. Numa classificação mais apurada e historicamente contextualizada, Galvão (1959) assim delineia a sua "área cultural Nordeste": "Dados os efeitos de aculturação à sociedade nacional, diversidade línguas e origens, temos certa dúvida em incluir todos esses grupos em uma única área" (173, p. 42). Trata-se, assim, inequivocamente, do que podemos chamar uma classificação residual.

Afastando-nos, porém do contexto etnológico do século XX e tentando buscar a percepção do colonizador quinhentista, veremos que tais aspectos marginalidade e residualidade - já se encontravam presentes na sua abordagem do conjunto extremamente heterogêneo dos povos habitantes da vasta região de caatingas que domina maior parte do interior do Nordeste, os "Tapuia" (inimigos contrários). Generalização tornada possível ao conhecimento colonial desses povos através da adoção do estigma expresso pelos seus interlocutores mais diretos, os Tupi da costa. [...] Tinha-se assim formada a polaridade básica que orientaria toda a apreensão colonial dos índios no Brasil, e que parece especialmente evidente no caso do Nordeste (p. 431-432).

[...] A partir da segunda metade do século [ref. XIX], sobretudo, os índios dos aldeamentos passam a ser referidos, com crescente frequência, como índios "misturados", agregando-se-lhes uma série de atributos negativos que os desqualificam e os opõem aos índios "puros" do passado, idealizados e apresentados como antepassados míticos (Dantas; Sampaio; CarvaIho, 1992, p. 451, grifos nossos).

A apresentação dessa série de elementos que vão criando o estigma acerca dos povos na região, pioneiramente trabalhadas pelo Pineb, são posteriormente refletidas por Oliveira (1999) e uma série de outros pesquisadores/as vinculados ao LACED - Laboratório de Pesquisas em Etnicidade, Cultura e Desenvolvimento em outro importante trabalho sobre tal contexto, o livro $A$ viagem da volta: etnicidade, política e reelaboração cultural no Nordeste Indígena, que apresenta reflexões sobre como a ideia de mistura foi fabricada, bem como os reflexos disso nas políticas de Estado.

No artigo introdutório a tal livro, o autor apresenta uma série de argumentos 
sobre a fabricação social de tal "mistura", bem como os resultados deste estigma nas políticas de governo. $\mathrm{O}$ autor menciona o "incômodo" do órgão oficial em trabalhar na região "justamente por seu alto grau de incorporação na economia e na sociedade regionais" (Oliveira, 1999, p. 17). Diferente do padrão de atuação da instituição, que ocorria em "situações de fronteira em expansão, com povos indígenas que mantinham sob seu controle amplos espaços territoriais [...] e que possuíam uma cultura manifestamente diferente daquela dos não-índios” (ibid.).

No Nordeste, contudo, os "índios" eram sertanejos pobres e sem acesso à terra, bem como desprovidos de forte contrastividade cultural. Em uma área de colonização antiga, com as formas econômicas e a malha fundiária definidas há mais de dois séculos, o órgão indigenista atuava apenas de maneira esporádica, respondendo tão somente às demandas mais incisivas que recebia. Mesmo nessas poucas e pontuais intervenções, o órgão indigenista tinha de justificar para si mesmo e para os poderes estaduais que o objeto de sua atuação era efetivamente composto por "índios", e não por meros "remanescentes" (Oliveira, 1999, p. 17-18).

Assim, com esta série de reflexões, objetivamos trazer à tona a ideia de que tanto a noção de sertão quanto a de "índios misturados" são produtos de uma construção histórica repleta de estigmas; e, por fim, os reflexos disso na ação do Estado.

\section{O semiárido e a caatinga}

Parte desta região que ao longo da história foi se construindo como o sertão do Nordeste hoje é denominada de Semiárido brasileiro. Ocupa aproximadamente $11 \%$ do território nacional e sua área de abrangência é definida em atos normativos do Poder Executivo Federal (atualmente definida pela Resolução 115/2017 da Superintendência de Desenvolvimento do Nordeste - Sudene). Além da Região Nordeste, estende-se para o norte do estado de Minas Gerais, englobando o Norte mineiro e o Vale do Jequitinhonha.

Criada como conceito que veio substituir o conhecido "polígono das secas", o uso do Semiárido como categoria de Estado tem sido objeto de sucessivas definições pelo aparato estatal. Sua primeira conceituação legal deu-se a partir da Lei Federal $\mathrm{n}^{\circ} 7$ 827, de 27 de setembro de 1989, delimitada pelo extinto Ministério da Integração Nacional, em substituição ao Polígono das Secas. Fruto de embates políticos, os conceitos de Polígono das Secas e posteriormente o de Semiárido foram criados como tentativa do poder público federal de mitigar os efeitos sociais decorrentes das secas que assolam historicamente a região.

Neste sentido, busca definir sua área de abrangência a partir de critérios climáticos (índices pluviométricos, risco de seca, deficit hídrico). Contudo, o caráter também político do processo (em particular a disputa por acesso a recursos financeiros específicos para municípios situados nesta área) levou a sucessivas alterações do conceito e, consequentemente, do formato e abrangência desta área reconhecida oficialmente (Albuquerque Júnior, 2018). O termo "Semiárido" vem 
sendo ressignificado pelos atores regionais como forma de contrapor e superar as práticas clientelistas do Estado de "combate à seca", substituindo-a pela noção de convivência com o Semiárido. Assim, com intervenção ativa de diversas organizações da sociedade civil, a noção de convivência com o Semiárido vem sendo gradativamente incorporada às políticas públicas voltadas à região (Albuquerque Júnior, 2018).

O Semiárido brasileiro reúne como características: precipitação pluviométrica média anual inferior a 800 milímetros (o regime irregular de chuvas), indice de aridez de até 0,5 considerando o periodo entre 1961 e 1990 (alto grau de incidência solar), e risco de seca maior que $60 \%$ (ocorrência frequente de secas). Ele abrange áreas de dois biomas, a Caatinga e o Cerrado, ambos caracterizados como florestas tropicais secas.

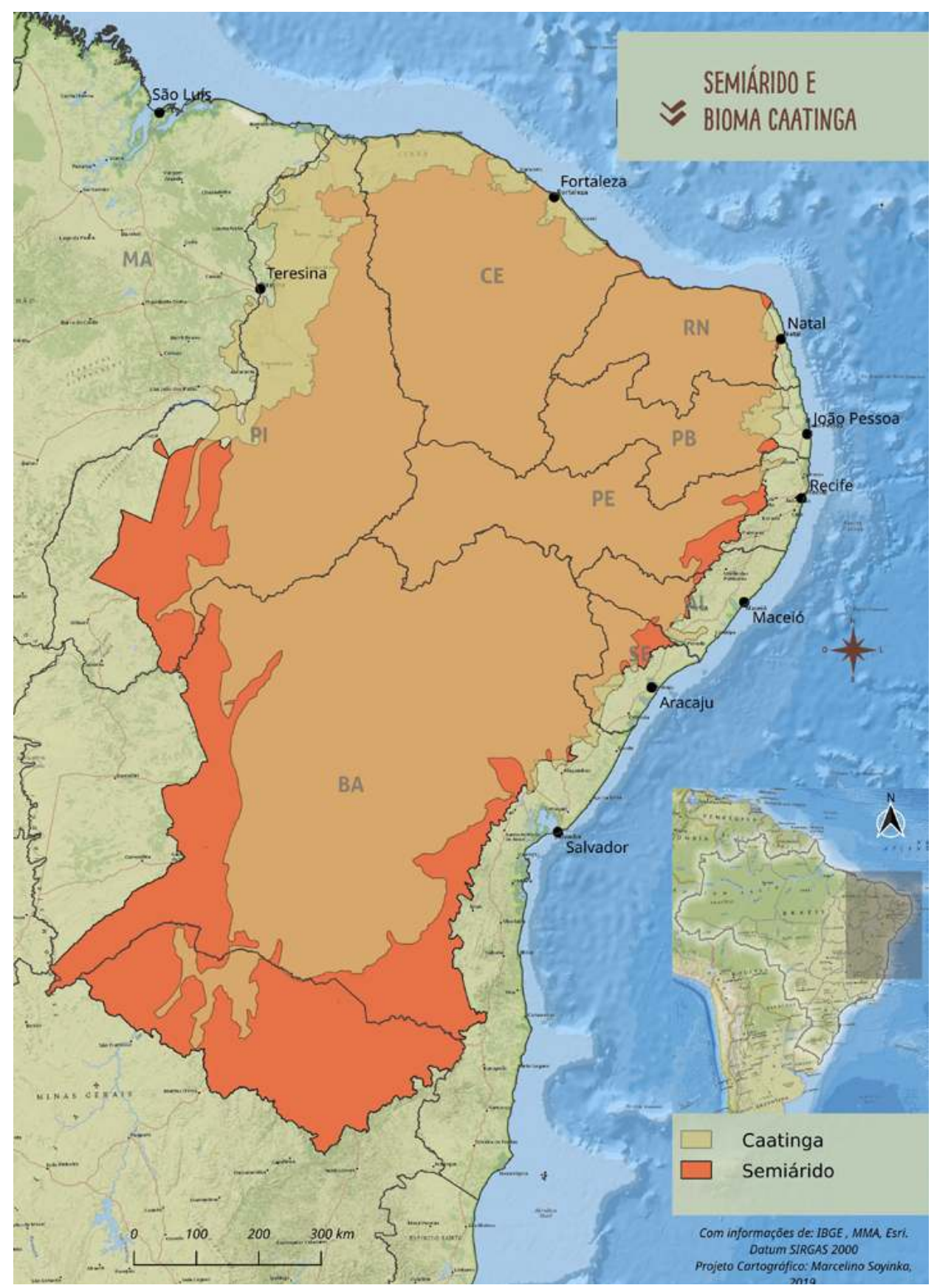

Mapa 1 - Semiárido e bioma caatinga 
A caatinga é o bioma que engloba nossos casos de pesquisa. Abrange área semelhante ao semiárido, cerca de $11 \%$ do território brasileiro, o que corresponde a $844.453 \mathrm{~km}^{2}$ (Mapa 1). É o único bioma situado exclusivamente em território nacional, sendo reconhecido por sua biodiversidade, além da heterogeneidade de suas formações vegetais e de espécies da fauna. Até o momento são conhecidas no bioma cerca de 178 espécies de mamíferos, 591 de aves, 177 de répteis, 79 espécies de anfíbios, 241 de peixes e 221 abelhas (BRASIL/MMA, 2019). Desse universo, $1 / 3$ das plantas e $15 \%$ da fauna são de espécies endêmicas - ou seja, que não são encontradas em outros locais do planeta (ASA, 2019).

\section{Unidades de Conservação (UC) de Proteção Integral na Caatinga}

Com quase metade (46\%) da vegetação nativa desmatada, a Caatinga é o terceiro bioma mais degradado do país, seguindo a Mata Atlântica e Cerrado (BRASIL, MMA/Ibama, 2016; ASA, 2019). Os principais motivos do desmatamento são o consumo de lenha nativa, explorada de forma ilegal e insustentável para fins industriais e domésticos, o sobrepastoreio e a conversão para pastagens e agricultura (BRASIL, MMA/Ibama, 2016). Outros elementos relevantes neste processo são os incêndios e queimadas, a caça predatória, mineração e crescimento urbano desordenado. Combinados, estes fatores levaram ao impressionante dado de que $80 \%$ da cobertura vegetal deste bioma encontra-se com algum grau de degradação (Freire et al., 2018, p. 11). Cabe mencionar que os efeitos deste desmatamento se agravam em função da região contar com as áreas mais suscetíveis a processos de desertificação, com muitos locais já em estágio avançado (Lima et al., 2011).

Segundo dados oficiais do Ministério do Meio Ambiente (BRASIL/MMA, 2016), 8,83\% da área da Caatinga encontra-se protegida através de Unidades de Conservação, totalizando 197 UCs (Mapa 2). Dentre estas áreas, 54 são classificadas como áreas de proteção integral (mais restritivas quanto ao acesso e presença humana em seu interior, somente permitindo uso indireto dos recursos naturais). As 143 áreas restantes incluem-se na categoria de Unidades de Uso Sustentável (categoria legal que permite formas distintas de atividades e ocupações humanas em seus limites, de acordo com a tipologia específica). Considerando-se apenas as UC's no regime de proteção integral, temos 1,8\% da área da caatinga protegida, dividida em 54 Unidades de Conservação.

É importante mencionar que a ênfase dada aqui às Unidades de Conservação de proteção integral justifica-se por serem desta categoria as áreas protegidas que incidem na região estudada, além das Terras Indígenas. Ao contrário das TIs, as UCs denominadas de proteção integral possuem uma série de restrições em relação ao acesso e permanência de humanos, bem como proíbe o uso e a exploração direta de qualquer natureza de recursos naturais em seu interior, conforme definidas em legislação (Lei 9.985/2.000). Destas 54 unidades de conservação de proteção integral existentes na caatinga, quatro estão situadas na região foco do presente estudo. São elas: Estação Ecológica do Raso da Catarina, Monumento Natural do Rio São Francisco, Parque Nacional do Catimbau e Reserva Biológica da Serra Negra. 


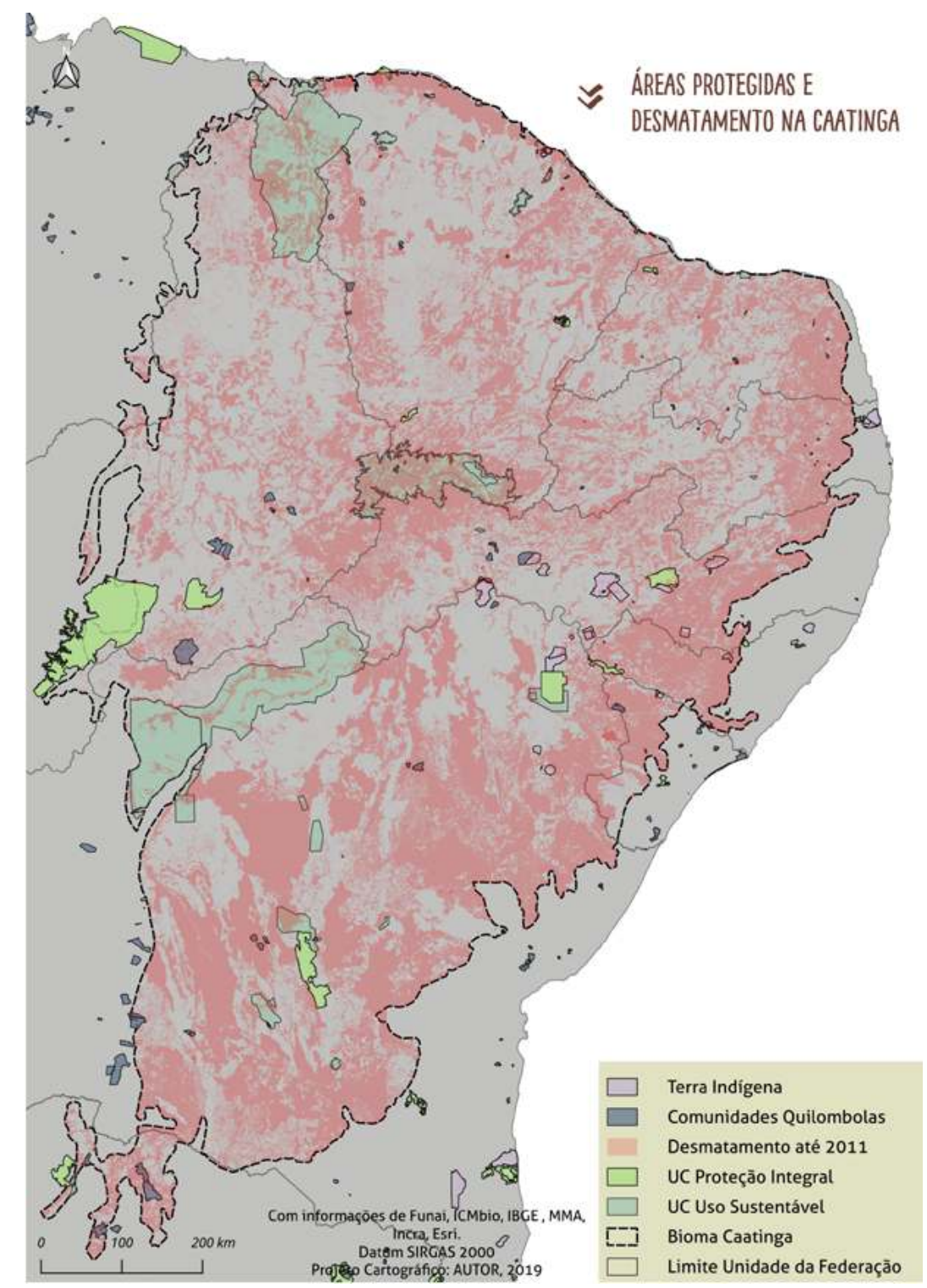

Mapa 2 - Áreas protegidas e desmatamento na caatinga

\begin{tabular}{|l|c|c|}
\hline \multicolumn{1}{|c|}{ Unidade de Conservação } & Extensão (hectares) & UF \\
\hline Reserva Biológica da Serra Negra & 624,85 & PE \\
\hline Estações Ecológicas do Seridó & $1.123,61$ & RN \\
\hline Parque Nacional de Ubajara & $6.269,51$ & $\mathrm{CE}$ \\
\hline Parque Nacional de Sete Cidades & $6.303,64$ & $\mathrm{PI}$ \\
\hline Parque Nacional da Furna Feia & $8.517,63$ & $\mathrm{RN}$ \\
\hline Parque Nacional de Jericoacoara & $8.862,85$ & $\mathrm{CE}$ \\
\hline Estação Ecológica de Área de Relevante Interesse Ecológico de Aiuaba & $11.746,78$ & $\mathrm{CE}$ \\
\hline Estação Ecológica do Castanhão & $12.574,64$ & $\mathrm{CE}$ \\
\hline Monumento Natural do Rio São Francisco & $26.736,30$ & $\mathrm{AL} / \mathrm{SE} / \mathrm{BA}$ \\
\hline Refúgio de Vida Silvestre da Ararinha Azul & $29.234,73$ & $\mathrm{BA}$ \\
\hline Parque Nacional Cavernas do Peruaçu & $56.448,32$ & $\mathrm{MG}$ \\
\hline Parque Nacional do Catimbau & $62.294,14$ & $\mathrm{PE}$ \\
\hline Parque Nacional da Serra da Capivara & $100.764,19$ & $\mathrm{PI}$ \\
\hline Estação Ecológica do Raso da Catarina & $104.844,40$ & $\mathrm{BA}$ \\
\hline Parque Nacional da Chapada Diamantina & $152.141,87$ & $\mathrm{BA}$ \\
\hline Parque Nacional do Boqueirão da Onça & $346.908,10$ & $\mathrm{BA}$ \\
\hline Parque Nacional da Serra das Confusões & $823.854,54$ & $\mathrm{PI}$ \\
\hline
\end{tabular}

Tabela 1 - Unidades de Conservação de Proteção Integral federais na Caatinga jan/2019

Fonte de dados: Sistema Nacional de Unidades de Conservação (SNUC), 2019. 


\section{A presença indígena no Semiárido brasileiro}

Além da biodiversidade, é imprescindível destacar a sociodiversidade existente no Semiárido: são 27 milhões de habitantes, o que equivale a nada menos que $12 \%$ da população brasileira (ASA, 2019). Destacam-se neste contexto aqueles grupos que historicamente têm mantido relações menos predatórias com o ambiente, chamadas de comunidades tradicionais. Alguns exemplos são as populações indígenas, quilombolas, pescadores artesanais, ribeirinhos, ciganos, comunidades de fundos de pastos e faxinais, etc.

A Região Nordeste registra a segunda maior população indígena no país: segundo os dados do último censo (IBGE, 2010), são mais de 230 mil indígenas, o que equivale a aproximadamente $1 / 4$ da população nacional dos chamados povos originários. Deste contingente, 45,6\%, ou seja, 106.142 pessoas, residem no interior das Terras Indígenas; e os outros 126.597, fora delas. Neste segundo grupo são contabilizados os indígenas que residem nos centros urbanos, seja nas cidades circunvizinhas às terras indígenas ou nas capitais. Igualmente estão considerados aqueles que não têm suas terras demarcadas. Tal realidade é em grande parte consequência da exígua demarcação de TIs na região, que via de regra consistem de áreas degradadas e insuficientes para a quantidade de famílias existente, o que faz com que várias delas necessitem se deslocar para outras localidades. Da população indígena da Região Nordeste, um contingente expressivo de 40\% (cerca de 93.400 indígenas) estão na área compreendida pelo Semiárido.

Os dados relativos aos quilombolas são igualmente significativos. Segundo a Fundação Cultural Palmares (2019), até agosto de 2019 a instituição havia expedido 2.744 certidões para Comunidades Remanescentes de Quilombos (CRQs) no Brasil. Deste total, a Região Nordeste contava com mais de 61\% do número de comunidades quilombolas do país, seguida do Sudeste com $16 \%$, Norte $-11 \%$, Sul - 7\% e Centro-Oeste - 5\% (Fundação Palmares, 2019). Há ainda toda uma gama de populações residentes na região do semiárido que possuem territorialidades, formas de vida, de uso e manejo de suas áreas e que em muitos casos não possuem reconhecimento oficial algum ou garantia de posse de seus territórios. Por conta desta invisibilidade frente ao Estado, tais comunidades são frequentemente alvo de agressões e esbulho territorial resultante de conflitos por uso e acesso de recursos naturais nas mesmas áreas que, frequentemente, encontram-se em grau de conservação mais elevado que áreas de entorno8.
8 A este respeito, exemplificam-se os casos de comunidades de fundos de pasto do sertão da Bahia e pescadores artesanais do submédio e baixo rio São Francisco (Nova Cartografia Socal, 2007 e 2012). 


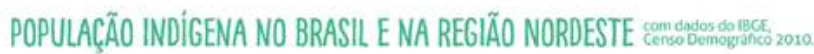
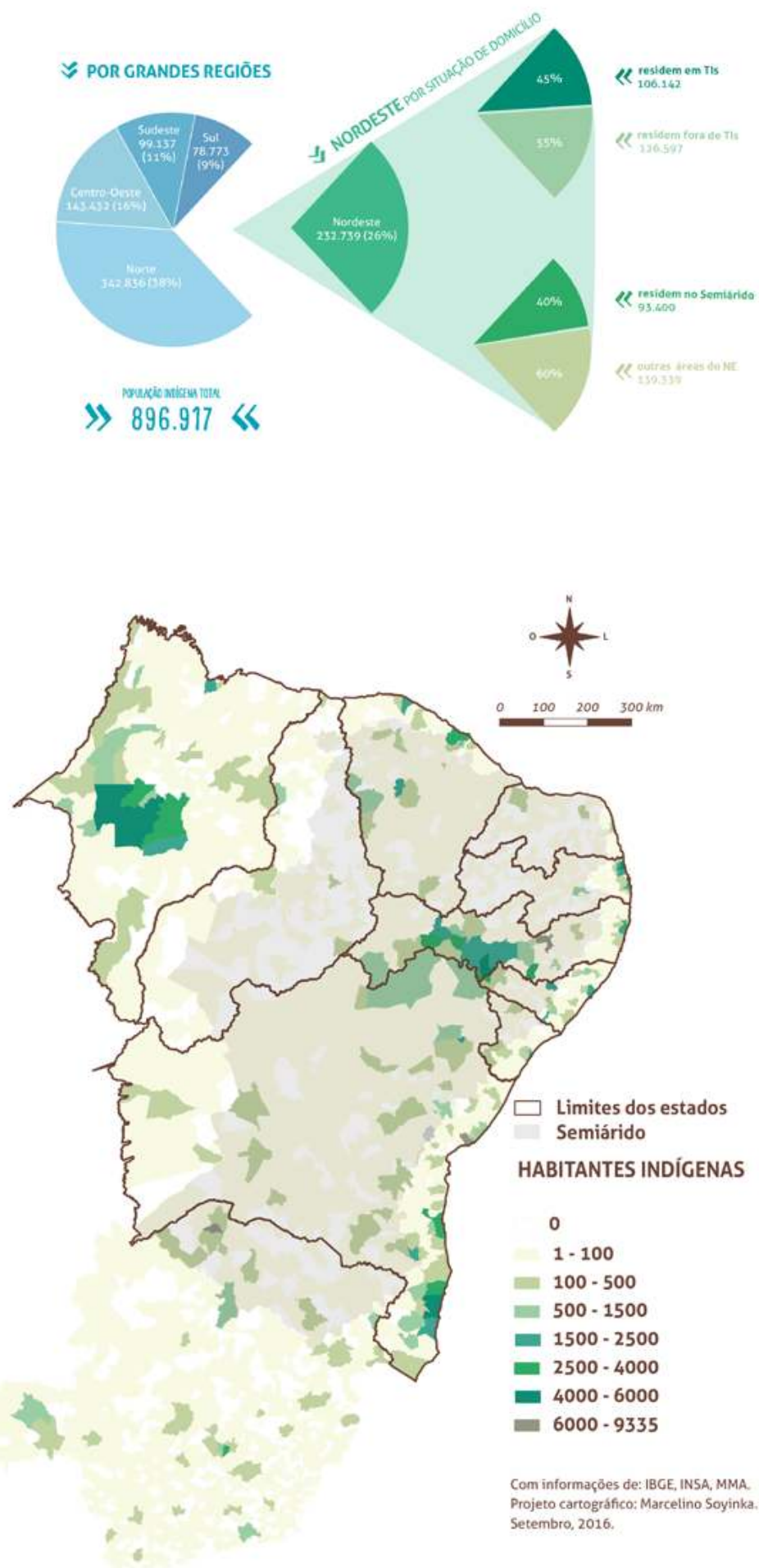

As áreas de estudo trabalhadas neste texto compreendem parte do Submédio e Baixo Rio São Francisco, na fronteira dos estados de Pernambuco, Alagoas, Sergipe e Bahia. É a região de agrupamento de municípios com maior quantidade de indígenas, como pode ser visto na mancha escura no Mapa 3.

Antes de dar prosseguimento à discussão das TIs em questão, é importante apontar alguns elementos que caracterizam as Terras Indígenas nessa região. $\mathrm{O}$
Infográfico 1 - População indígena no Brasil e na Região Nordeste

Mapa 3 - População indígena no Semiárido 
primeiro deles é que as pequenas porções dos territórios tradicionais regularizados como TIs não foram ao longo dos últimos séculos de domínio exclusivo e ininterrupto dos indígenas. Ao contrário, essas áreas foram invadidas de formas diversas, seja por pequenos posseiros ou grandes fazendeiros. Muitas vezes tais investidas foram inclusive incentivadas pelos poderes coloniais e do Estado brasileiro. A condição das famílias indígenas nesses contextos variou entre: permanecerem comprimidos em pequena porção de terra; serem expulsos de forma total ou parcial; ou ainda permanecerem e tornarem-se moradores/arrendatários/ meeiros dos invasores de seus territórios (Anaí, 2014).

Em consequência desta expansão colonial, as áreas que restaram a estes povos estão frequentemente distantes das localidades mais férteis à agricultura e das melhores fontes de água, via de regra incorporadas a grandes propriedades privadas de terra. É importante considerar que, em se tratando do Semiárido, o acesso à água é uma das principais questões para a população, tanto para a sobrevivência mais imediata quanto para as atividades produtivas e dessedentação animal (Anaí, 2014).

Grande parte dos territórios tradicionais só começaram a ser parcialmente regularizados como Terra Indígena a partir da mobilização política dos indígenas, principalmente ao longo das últimas três décadas, após a Constituição de 1988. Porém, mesmo após as poucas demarcações, as áreas que retornaram ao domínio indígena são marcadas pelos longos períodos da dominação externa, uma paisagem caracterizada pela ocorrência de forte degradação ambiental consequente destes processos, bem como pela presença de pastagens e monocultura. Neste contexto, o que os indígenas retomam enquanto território foram terras arrasadas, no que se refere aos recursos naturais. É interessante apontar ainda que, assim que voltam às mãos dos indígenas, essas porções de terra são reapropriadas e repartidas pelas comunidades. Há nesses contextos uma forte pressão demográfica e econômica a estes territórios diminutos e fragmentados (Anaí, 2014), o que implica em desafios na reprodução de sua territorialidade diante do cenário de tantas limitações. 


\section{Terras Indígenas: áreas protegidas no semiárido brasileiro}

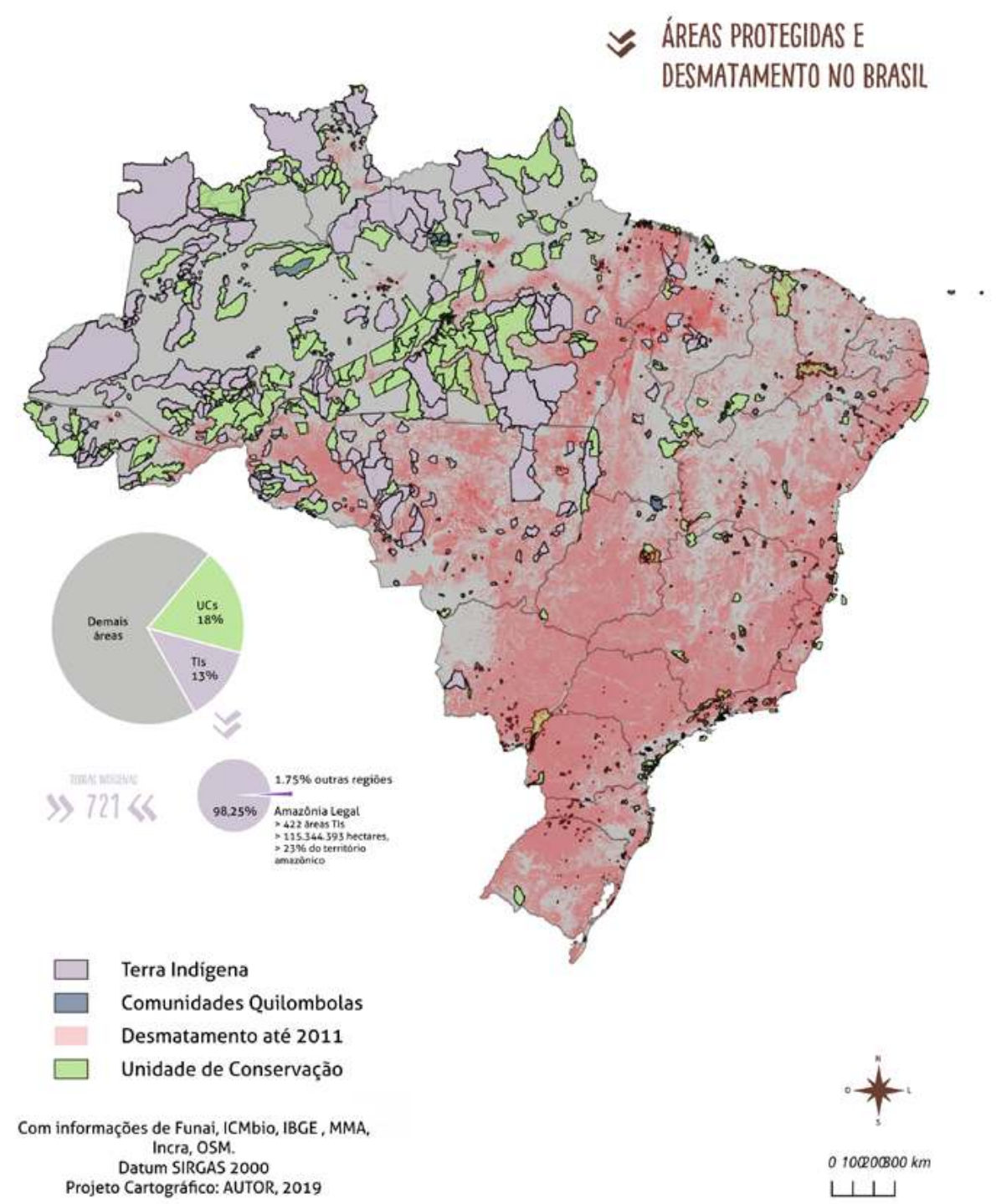

No Mapa 4 é possível constatar como as regiões não desmatadas no Brasil estão, principalmente, no interior de Terras Indígenas e Unidades de Conservação. No total, as Unidades de Conservação e as TIs correspondem a mais de $30 \%$ do território nacional. As UCs com 18\%, e as TIs com aproximadamente $13 \%$.

Neste contingente estão inclusas 616 Terras Indígenas (Funai, 2019). Não obstante, uma quantidade expressiva destas áreas não conta com o processo de regularização concluído, implicando na não garantia completa dos direitos indígenas a seus territórios ${ }^{9}$. É igualmente evidente, ao observar o mapa, o quão diminutas são as TIs fora da Amazônia Legal. Na Amazônia Legal, as TIs cobrem e protegem significativas proporções de terras das Unidades da Federação, chegando a 46,30\% em Roraima, e pouco menos de $10 \%$ em estados como o Tocantins (9,36\%) e o Maranhão (7,38\%). Somam 22,29\% da área de toda a Amazônia Legal (ISA, 2016).

Já no Semiárido, as poucas terras demarcadas possuem tamanhos diminutos, com as menores alcançando até menos de cem hectares. Na Região Nordeste, em
Mapa 4 - Áreas protegidas e desmatamento no Brasil
9 Embora o direito dos povos indígenas a seus territórios tradicionais esteja garantido na Constituição Federal de 1988 (art. 231), o processo administrativo de demarcação que efetiva este direito é composto por diversas fases até sua regularização de fato (as etapas do procedimento são descritas no Decreto Presidencial 1.775/1996). Tais procedimentos geralmente arrastam-se por anos, e mesmo áreas já demarcadas há bastante tempo frequentemente não contam com o processo concluído. Dados de abril de 2019 da Funai indicam que das 616 Terras Indígenas atualmente demarcadas pelo estado brasileiro, $436(70,7 \%)$ encontram-se com todas as fases legais do processo demarcatório conclusas (FUNAI, 2019). Ou seja: praticamente um terço das Terras Indígenas ainda se encontra com processo demarcatório inconcluso, o que gera insegurança aos indígenas quanto a garantia de seus direitos, e consequentemente potencializa risco de conflitos associados à posse da terra. 
nenhuma Unidade da Federação as terras demarcadas para os povos indígenas atingem sequer $1 \%$ das áreas destes estados. O percentual da área das terras indígenas relativa ao território total também é diminuto: são 0,42\% relativos à caatinga e 2,14\% relativos à Região Nordeste.

É interessante observar comentários de Oliveira (1999) sobre tal aspecto:

comparo os povos indígenas que estão na Região Nordeste com aqueles da Amazônia em termos dos territórios que ocupam ou reivindicam. Dadas as características e a cronologia da expansão das fronteiras na Amazônia, os povos indígenas detêm parte significativa de seus territórios e nichos ecológicos, enquanto no Nordeste tais áreas foram incorporadas por fluxos colonizadores anteriores, não diferindo muito as suas posses atuais do padrão camponês e estando entremeadas à população regional.

Essa desproporção dá aos problemas e mobilizações dos povos indígenas na Amazônia uma importante dimensão ambiental e geopolítica, enquanto no Nordeste as questões se mantêm primordialmente nas esferas fundiária e de intervenção assistencial. Se na Amazônia, a mais grave ameaça é a invasão dos territórios indígenas e a degradação de seus recursos ambientais, no caso do Nordeste, o desafio à ação indigenista é restabelecer os territórios indígenas, promovendo a retirada dos não-índios das áreas indígenas, desnaturalizando a "mistura" como única via de sobrevivência e cidadania (grifos no original) (Oliveira, 1999, p. 18).

Apesar de escritas há vinte anos, as reflexões apresentadas pelo autor ainda se encontram atuais. Porém, vale mencionar que, ao longo destas últimas duas décadas, inúmeras das TIs avançaram no processo de regularização fundiária. Mesmo nos casos em que o processo de regularização fundiária se encontra finalizado (ainda que em boa parte sejam insuficientes de acordo com a territorialidade indígena), uma questão que se coloca para os indígenas é: como gerir estes territórios (muitas vezes apenas parte deles) altamente degradados que retornam às suas mãos? É partir deste cenário que a temática passa a ser pauta do movimento indígena no Nordeste, e assim também no âmbito da construção e execução da PNGATI. Esta nova conjuntura traz a discussão da gestão territorial para um local de relevância na pauta do movimento e então provoca o âmbito da produção acadêmica nesse sentido. É assim que nos sentimos incitados a escrever este texto. 


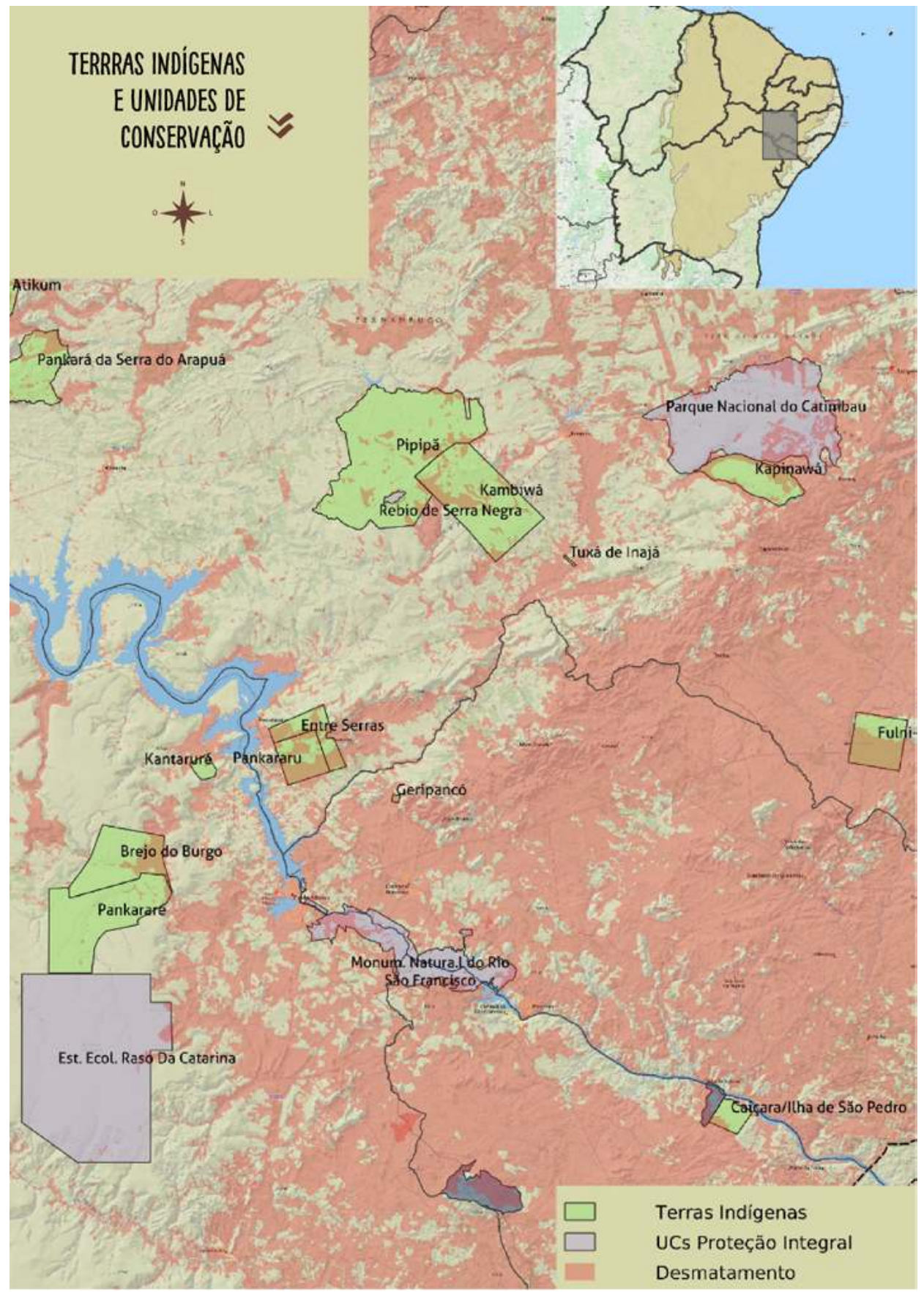

Apesar de tratar de realidades bastante distintas da região amazônica - conforme já mencionado, são áreas com dezenas de milhares de hectares de diferença, dentre outras particularidades -, percebe-se que as Terras Indígenas no Semiárido brasileiro (e por consequência as formas de os povos indígenas ocuparem e viverem em seus territórios) têm atuado em parte como barreiras que têm tido como uma consequência a proteção da biodiversidade nestes locais.

Lembramos que, por tratar de área de ocupação colonial mais antiga, consiste também na região em que os efeitos indesejados desta ocupação (invasão) se fazem sentir mais intensamente: neste sentido o Mapa 4 é eloquente ao apresentar os dados de degradação do território, bem como seu contraste com a insuficiência de áreas com algum grau de proteção para fazer frente a este processo.

Apesar deste panorama apresentado, é comum encontrar relevantes porções
Mapa 5 - Terras Indígenas e Unidades de Conservação (região de recorte da pesquisa) 
de vegetação nativa conservadas no interior das terras indígenas do contexto aqui estudado. Não acreditamos que é por acaso que, na região aqui trabalhada, as Unidades de Conservação Federais situam-se vizinhas ou sobrepostas às Terras Indígenas. Aqui apresentamos particularmente o recorte da área trabalhada, que abrange parte do submédio e baixo São Francisco. Neste recorte encontram-se a Estação Ecológica do Raso da Catarina contígua a TI Pankararé; o Parque Nacional do Catimbau, também contíguo a TI Kapinawá, porém neste contexto há uma situação de sobreposição à parte do território que ainda se encontra pendente de regularização; e, por fim, a Reserva Biológica da Serra Negra, que se encontra sobreposta à TI Pipipã e vizinha a TI Kambiwá (ver Mapa 5).

Tratando de um recorte ainda mais reduzido, particularmente das Terras Indígenas referidas na introdução deste artigo, há aspectos que reforçam o que foi argumentado sobre a cobertura vegetal da caatinga nas TIs. Observaremos na seção seguinte que as áreas de caatinga conservadas estão intrinsecamente ligadas à maneira de manejo deste território pelas famílias que ali vivem.

\section{Os casos em estudo}

Argumentamos até o momento que a presença de áreas com fragmentos ou grandes porções de matas de caatinga conservadas no interior dos territórios relaciona-se com a lógica dos indígenas e seus modos de vida de ocupação de seus territórios, mas como isso é posto em prática na vida cotidiana? Como os povos indígenas estabelecem estas relações? E quais os níveis específicos das mesmas? Nesta seção buscaremos apontar algum dos aspectos observados em cada um dos casos apresentados.

De forma breve, pode-se afirmar que os territórios indígenas com os quais trabalhamos são compostos por dezenas de aldeias (à exceção dos Xokó, que estão todos reunidos em uma única povoação). Nestes territórios há uma série de unidades espaciais que são fundamentais na compreensão da vida cotidiana, quais sejam: as aldeias, as unidades domésticas (casas mais terreiros/quintais), as roças, e as matas.

As aldeias são compostas por grupos familiares que possuem um vínculo de parentesco mais próximo. Na ordenação territorial de tais espaços, como "norma" geral percebem-se as unidades domésticas formadas por uma casa rodeada por um terreiro/quintal que, por sua vez, é delineado por uma cerca de arame farpado e/ou por varas de madeira justapostas. Normalmente, os terreiros das casas se põem ladeados uns aos outros, ao longo de uma ou duas ruas que cruzam as aldeias. É muito comum que estes quintais comportem também pequeno grupo de outras casas dos/as filhos/as das lideranças familiares - principalmente nas aldeias mais populosas e densamente povoadas. No caso Xokó, há uma única aldeia, e as casas se distribuem em dois arruados e sem cercas.

As roças, por sua vez, encontram-se mais afastadas do núcleo das residências. Há em muitos casos pessoas que possuem roças em locais diferentes, nos arredores de aldeias que não são necessariamente as suas de moradia. Isso se dá em função das diferentes condições produtivas (em função do clima, relevo, fertilidade do solo, acesso, dentre outras) que o território abarca e indica, de acordo 
com os saberes e a experiência dos indígenas, o que é propício para cultivar em cada localidade.

Por fim, as matas, que são o locus de interesse deste artigo, fazem parte de um conjunto de relações, das quais destacamos três elementos relevantes, denominados aqui de "níveis": econômico, da saúde e religioso. Explicita-se aqui que a exposição e a nomenclatura de "níveis" é utilizada aqui apenas como artificio didático, e que de forma alguma deve ser compreendido como hierarquização de qualquer natureza destes conceitos. Tampouco devem ser considerados como elementos estanques e isolados: os "níveis" aqui referidos se perpassam, tocando transversalmente uns aos outros e relacionando-se entre si.

O primeiro "nivvel" referido é o econômico. A manutenção das matas é fundamental na estrutura econômica destas comunidades, que possuem como base fundamental de sobrevivência: a agricultura; a pecuária - principalmente de caprinos; em menor escala, o artesanato; acompanhadas igualmente de outras fontes de renda oriundas de subsídios estatais, como aposentadorias rurais e nas últimas décadas empregos gerados pelos serviços de saúde e educação que atendem os povos indígenas.

No caso dos Xokó, adiciona-se a pesca enquanto atividade historicamente relevante para o grupo. Contudo, com a construção das sucessivas hidrelétricas ao longo do curso do Rio São Francisco, bem como sua progressiva degradação e interrupção dos ciclos de cheia e vazante, a atividade entrou em declínio.

Na pecuária, principalmente na criação de caprinos, a presença das matas é vista sob dois aspectos: como fonte de recursos para a alimentação animal, uma vez que os rebanhos são criados soltos e alimentam-se da vegetação nativa durante parte do ano (em alternativa ao uso de rações); e a presença de fragmentos de mata é igualmente importante enquanto fonte de madeira para a construção de currais, cercados e demais estruturas necessárias para a criação dos rebanhos.

Fragmentos florestais são também fontes de matéria-prima para uma série de objetos de artesanato que são confeccionados nas comunidades. Alguns dos elementos utilizados são madeiras de árvores, fibras vegetais, sementes, barro para confecção de peças de cerâmica e tinturas. Os dois últimos são comumente extraídos também fora das matas.

Estas matérias-primas muitas vezes são reunidas a materiais comprados fora das aldeias, e/ou coletados nos terreiros das residências para confecção das peças. Aqui o artesanato transpassa, principalmente, dois dos níveis citados de relação: sua confecção e comercialização é importante enquanto fonte de renda, mas também há determinados itens produzidos com estas técnicas que possuem agência como elementos constitutivos das relações rituais (por exemplo: roupas de Praiás, maracás utilizados nos rituais, etc.).

No "tempo dos mais velhos", associado frequentemente ao período de luta pela posse da terra, marcada por períodos de seca, de violências e de carestia, as áreas de mata associadas a regiões consideradas de difícil acesso frequentemente atuaram como locais de refúgio para os indígenas das agressões das frentes de expansão da sociedade nacional sobre seus territórios. Nesses períodos, os três po- 
vos aqui relacionados relatam a dificuldade de se manterem, seja pelas condições climáticas adversas, como pela dificuldade no acesso a áreas que possibilitassem suas práticas agrícolas. É preciso considerar que as territorialidades indígenas são calcadas em usos múltiplos do território, baseado em suas cosmovisões. Desta forma, com o avanço das frentes de expansão da sociedade nacional, as regiões de mata, sempre associadas a formas de uso e ocupação específicos e complementares a outras atividades (pesca, agricultura), assumiram então o papel de principal fonte de recursos alimentares. Estas informações são comuns nos relatos, em que falam sobre a "comida braba", via de regra baseada em atividades extrativismo vegetal (coleta de pequenos frutos nativos como macaúba, quixaba, umbu, etc), mel de abelhas nativas diversas ou caça.

O segundo nivel que sublinhamos é o da saúde. Nas áreas de matas são encontrados os elementos centrais para a saúde na vida cotidiana dos indígenas. Entrelaçado com os demais níveis, boa parte dos remédios utilizados na medicina tradicional é proveniente de elementos presentes na flora e fauna nativa: são inúmeras cascas, folhas e raízes utilizadas em "garrafadas", chás, infusões ou banhos em tratamentos terapêuticos. Muitas vezes, estes são associados a tratamentos de ordem espiritual/religiosa, evidenciando uma interligação na prática que transcende à divisão utilizada aqui apenas para fins didáticos nos denominados "níveis".

Também se relaciona à presença de cobertura vegetal nativa a ocorrência das nascentes de água, fonte de parte do abastecimento das residências, principalmente na TI Pankararu. Nesta TI, os adultos são unânimes em recordar que, em sua juventude, tratava-se inclusive da única fonte de água disponível nas aldeias. Atualmente, são comuns os relatos da diminuição do fluxo da água em função do desmatamento destes locais. Por conseguinte, nas discussões da gestão territorial e ambiental da TI Pankararu, uma das principais questões indicadas foi justamente a demanda por reflorestamento das áreas de nascentes.

O terceiro nivel de relações que gostaríamos de destacar são as religiosas. Os povos indígenas possuem em sua relação com o sagrado/ritual um dos elementos centrais definidores de sua identidade. No caso dos povos em questão, em que pesem suas reconfigurações como fruto dos processos históricos de contínuas agressões físicas e simbólicas à sua existência, tais questões frequentemente se associam a elementos daquilo que os não indígenas concebem como "natureza", tais como cachoeiras, matas, grotas e outros elementos da paisagem. Neste sentido, as áreas de seus territórios que contêm alguns destes elementos revestem-se de valor intangível, que transcende o mero valor utilitário como "fonte de recursos naturais". Ao contrário, são locais que frequentemente contam com interdições totais de acesso ou mesmo um conjunto de normas rígidas para acessá-los, só sendo possível para pessoas dotadas de preparos especiais ("pajés", líderes espirituais) ou em ocasiões específicas - os rituais.

Como consequência destes processos de significação, tais locais sagrados e entornos frequentemente convertem-se em regiões de exploração menos intensiva, atuando como locais de refúgio para fauna e flora local, resultando naquilo que os conservacionistas chamariam de áreas conservadas de biodiversidade. Como con- 
sequência, a conservação destes sítios sagrados de forma íntegra é vista internamente como algo fundamental para a sobrevivência física e cultural destes povos, já que muitos dos elementos utilizados nos rituais (como a jurema e o caroá, por exemplo, que serão tratados de forma mais detalhada a seguir) são extraídos justamente destas matas e são estas mesmas plantas, elementos sagrados "de poder".

Não obstante todos estes processos, ainda assim observa-se que estas áreas indígenas concentram uma cobertura vegetal nativa mais expressiva do que as áreas de seu entorno, conforme pode ser conferido nos mapas a seguir. É justamente a conservação destas "ilhas" de vegetação que refletem e evidenciam esta forma diferenciada de significação, uso e ocupação do território e de seus elementos de forma bastante diversa daquela do entorno ocupado por não indígenas.

Ao observar os mapas a seguir é possível perceber que nos três casos apresentados (TIs Caiçara/Ilha de São Pedro, Pankararu/Entre Serras e Kapinawá) as terras indígenas apresentam uma expressiva porção de sua área ainda - ou novamente - recoberta pelas formações vegetacionais da caatinga no interior das terras indígenas. Vejamos o caso de cada uma delas.

Cabe aqui a ressalva de que tais mapas foram produzidos com o intuito ilustrativo para fins de fomentar a discussão interna destes grupos sobre seus territórios, e que portanto contaram com metodologias e técnicas de produção distintas daquelas que perpassam estudos específicos das dinâmicas de cobertura e uso do solo ${ }^{10}$. Não obstante, os resultados apresentados são suficientes para o intento deste ensaio: fornecer indícios da importância da garantia dos direitos territoriais indígenas não só em seus processos sociais, mas também para questões ambientais cujas consequências extrapolam em muito as áreas de seus territórios, principalmente em ambientes carentes de iniciativas estatais de conservação como a Caatinga e o Semiárido.
10 Estudos neste sentido têm sido capitaneados pelas agências governamentais de meio ambiente, caso do Ministério do Meio Ambiente - MMA e seu Projeto de Monitoramento do Desmatamento dos Biomas Brasileiros por Satélite - PMDBBS e, mais recentemente, pela iniciativa intitulada MAPBIOMAS, que consiste em uma rede formada por ONGs, universidades e empresas de tecnologia organizada por biomas e temas transversais. 


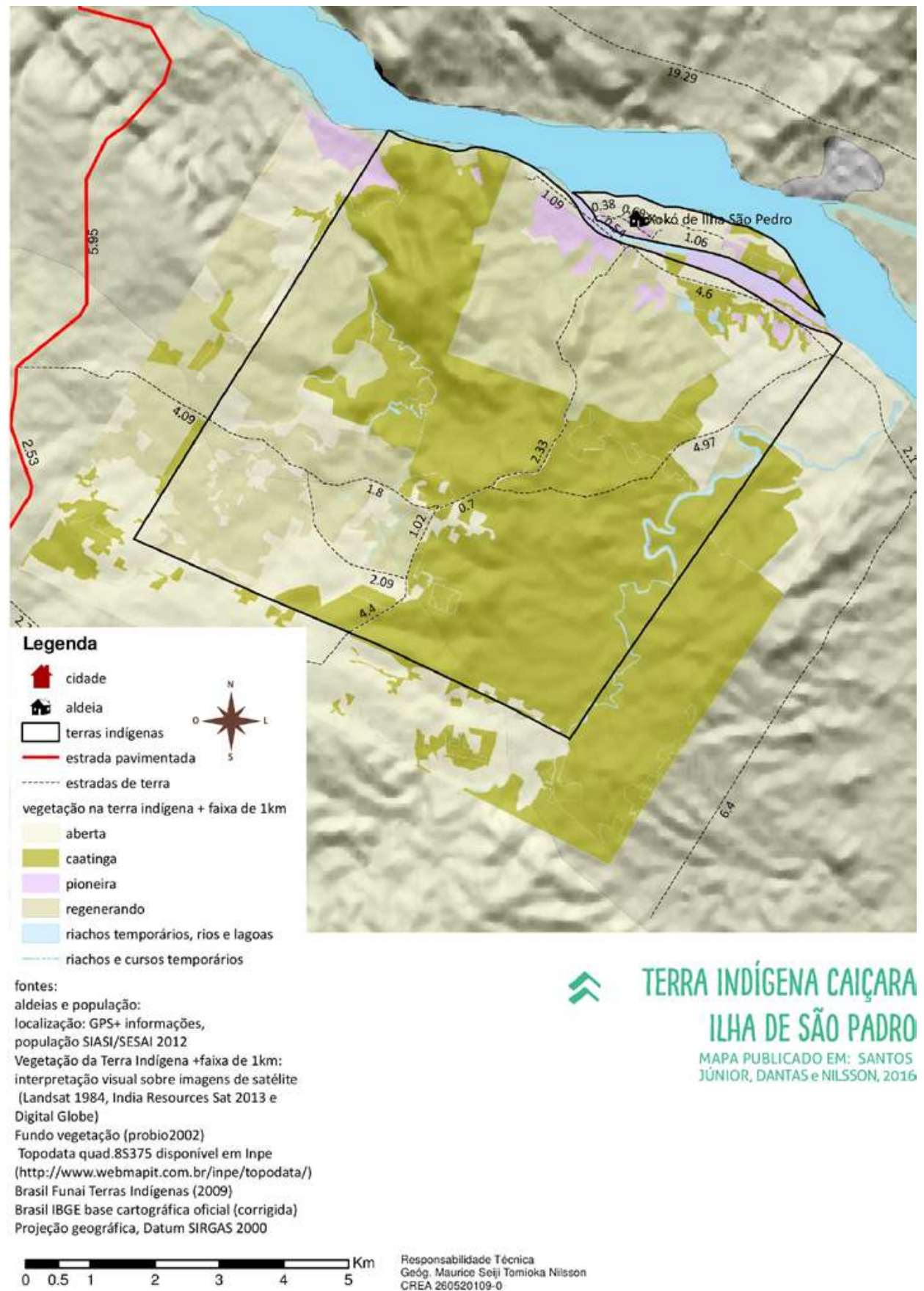

No caso Xokó, observa-se que no interior da Terra Indígena há o maior percentual de área de cobertura vegetal nativa. Sublinhamos neste caso a significativa porção que está novamente coberta de vegetação nativa - há uma expressiva recomposição da cobertura vegetal que coincide justamente com o período após demarcação da área e retorno dos indígenas ao seu território, antes intrusado por uma fazenda de gado e ocupado por pastagens (Santos Júnior et al., 2016). No Mapa 6, a região que foi recoberta pelas formações de caatinga está sublinhada em verde claro, com a legenda "regenerando". Percebe-se também que há uma presença das chamadas "formações pioneiras" (em rosa), que são formas de vegetação típicas de áreas previamente desmatadas e que se encontram atualmente em estágio inicial de recomposição.
Mapa 6 - Terra Indígena Caiçara/ Ilha de São Pedro 


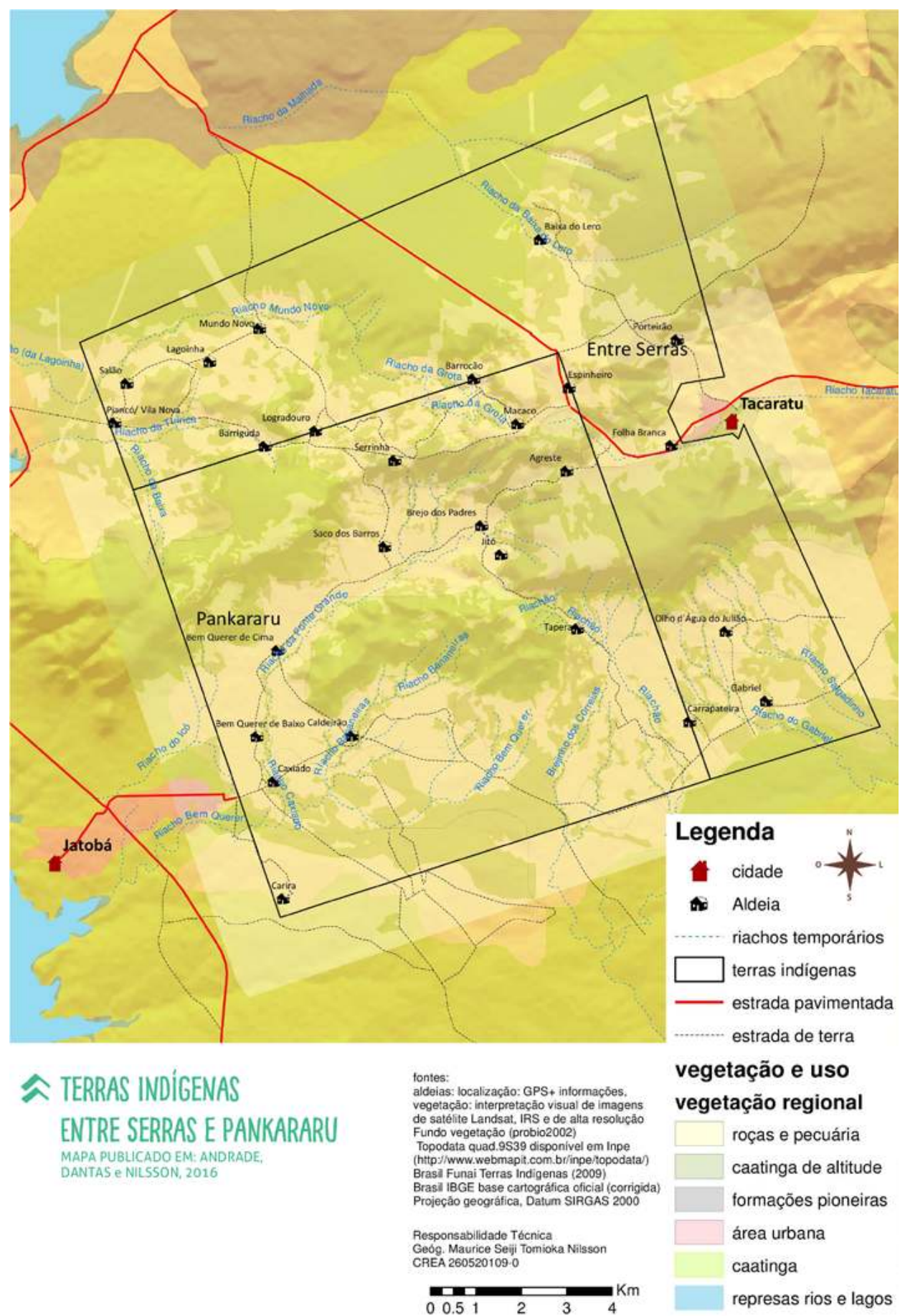

Mapa 7 - Terras Indígenas Entre Serras e Pankararu

No caso de Pankararu, destacamos que a área mais desmatada, com a legenda "roças e pecuária" (em amarelo), encontra-se justamente na região que até recentemente estava na posse de não indígenas - a extrusão dos posseiros da área foi realizada apenas no decorrer de 2018. No Mapa 7, tal área corresponde à parte sudoeste, quadrante inferior esquerdo do quadrilátero da referida TI.

As regiões com cobertura vegetal se encontram principalmente nos altos das serras, o que é de suma importância pois é onde estão situadas as nascentes de água, bem como nas regiões afastadas dos centros urbanos de Jatobá e Tacaratu.

No caso dos Pankararu, dois elementos materializam o exposto acima de maneira exemplar: o caroá, ou croá (Neoglasiovia variegata) e o umbu (Spondias tube- 
rosa). O primeiro consiste em um tipo de bromélia de ocorrência relativamente comum em áreas de caatinga, cuja fibra é utilizada como matéria-prima na confecção de diversos artefatos, tais como bolsas (os tradicionais aiós) e cordas. Seu principal uso atual pelos indígenas é na confecção dos trajes rituais dos Praiás (um tipo de máscara que recobre todo o corpo utilizado em momentos rituais entre os Pankararu para incorporar os encantados) elementos centrais da prática ritual deste povo. Trata-se de uma espécie vegetal cujo uso provém apenas do extrativismo, na qual a coleta e o uso também são mediados por questões rituais, e por esta razão é cercado de segredos. Pode ser considerada como uma das plantas mais importantes no universo cultural do povo Pankararu (Anaí, 2015).

O umbu (Spondias tuberosa) também se caracteriza como elemento central na vida deste povo: além de seus usos na alimentação, o ciclo da espécie é utilizado como referência de todo um complexo de rituais, que inclusive recebe o nome da fruta. O ciclo ritual inicia-se com o chamado "Flechamento do umbu", que ocorre com o aparecimento das primeiras frutificações do ciclo anual da espécie. Tem continuidade nos meses seguintes com outras festividades, como a "Corrida do umbu".

Cabe ressaltar que, a despeito da relevância das matas e seus elementos para vida dos indígenas, conforme tem sido evidenciado ao longo do texto, contingências históricas de restrição territorial e mudanças nos padrões de consumo têm ocasionado alterações nos processos de uso e ocupação do território. Estes fatores têm implicado em mudanças significativas nos impactos de atividades tradicionais nos recursos naturais. Um exemplo destes processos pode ser observado na alteração da dinâmica do uso do Caroá pelo povo Pankararu. Conforme já citado, a espécie se reveste de importância cultural fundamental para este povo. Em decorrência deste uso e da retomada do crescimento populacional indígena ocorrida ao longo das últimas décadas, tem aumentado a pressão de extração do croá nas áreas do interior da Terra Indígena, além da capacidade de regeneração da espécie. Este fato já vem sendo notado pelos indígenas, que buscam soluções alternativas à questão da crescente escassez de croá percebida na região. Não obstante, tal fato evidencia os novos desafios que se colocam aos indígenas ao (re)produzir suas territorialidades em contextos de confinamento a espaços delimitados, e cujo entorno, em outros períodos livremente utilizados, encontra-se num processo de densa ocupação ou forte degradação ambiental. O caso particular reveste-se de maior gravidade ao levar em consideração que a TI Pankararu, apesar de identificada desde 1987, encontrava-se até o ano de 2018 com mais da metade de seu território ocupada por posseiros não indígenas.

Os dados percentuais da cobertura vegetal nas TIs mencionadas corroboram o que foi dito. A quantidade de área de caatinga conservada corresponde, por exemplo, ao tamanho de algumas Unidades de Conservação de menor porte. Observando-se a Tabela 1, percebe-se que um terço das UCs de proteção integral, por exemplo, possui área menor que 10.000 ha. 


\begin{tabular}{|c|c|c|c|c|}
\hline \multirow[t]{2}{*}{ Terra Indígena } & \multicolumn{2}{|c|}{$\begin{array}{c}\text { Vegetação } \\
\text { (em \% da área) }\end{array}$} & \multirow{2}{*}{$\begin{array}{c}\text { Dimensão } \\
\text { da TI }\end{array}$} & \multirow{2}{*}{$\begin{array}{c}\text { Área de } \\
\text { caatinga } \\
\text { preservada }\end{array}$} \\
\hline & Aberta & Caatinga & & \\
\hline Entre Serras & 38,88 & 61,05 & 7.750 ha & $4.766,25$ ha \\
\hline Pankararu & 53,93 & 46,07 & 8.100 ha & $3.731,67$ ha \\
\hline Caiçara /llha de São Pedro & 18,76 & 81,24 & 4.316 ha & $3.506,31$ ha \\
\hline
\end{tabular}

Tabela 2 - Cobertura Vegetal nas Terras Indígenas dos Pankararu e Xokó

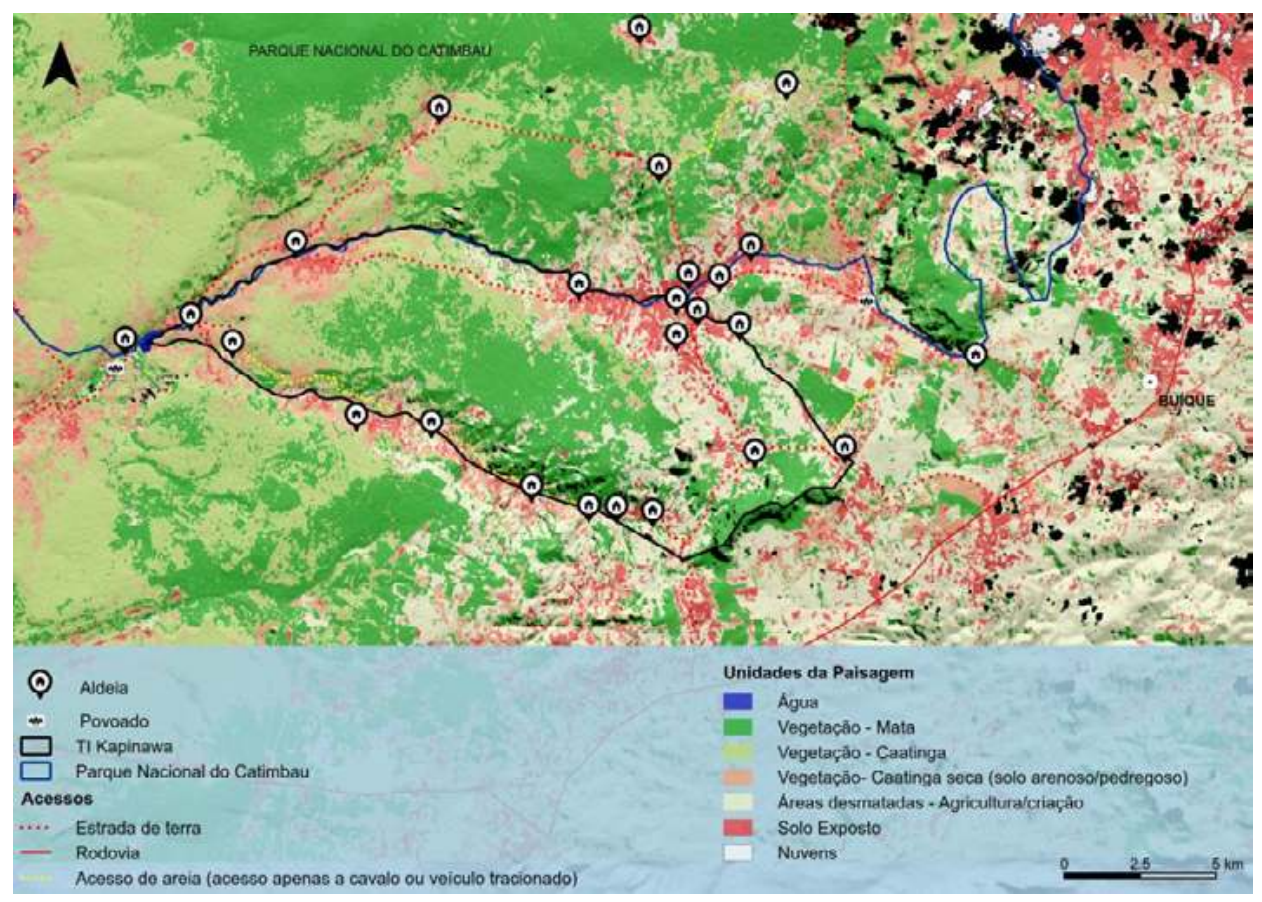

Por fim, citamos o caso Kapinawá. Ao se examinar o Mapa 8, percebe-se que a cobertura vegetal da parte esquerda do mapa, que corresponde a TI Kapinawá e ao Parque Nacional do Catimbau, contrasta com a parte direita, que tem a maior parte do solo desmatada. Hoje o município de Buíque, que abarca este contexto, tem o maior rebanho bovino do estado de Pernambuco (IBGE, 2019). Na década de 1970/80, proprietários de fazendas de gado da região tentaram tomar as terras dos indígenas através de grilagem. As famílias kapinawá resistiram a tal investida, o que ocasionou um conflito fundiário agudo entre os anos de 1979 e 1983.

Através dessa resistência ativa, impediram que suas áreas de uso fossem transformadas em grandes pastagens de gado, tal qual ocorreu nas demais áreas do município. Essa resistência dos indígenas funcionou como uma espécie de barreira de proteção para a região, que hoje corresponde ao Parque Nacional do Catimbau, UC que foi criada em 2002 sobrepondo-se à parte do território kapinawá que ainda se encontra pendente de regularização (observar os pontos marcados como aldeias indígenas no Mapa 8).

Como podemos notar, as Terras Indígenas ainda são alguns dos principais redutos com áreas de cobertura vegetal expressiva da Caatinga conservada em seus contextos regionais. Se comparadas às regiões de entorno, as Terras Indígenas no Brasil compreendem significativa parcela de suas áreas com sua cobertura vegetal íntegra, com grande diversidade de espécies servindo de habitat de refúgio para fauna.

Não obstante a necessidade de estudos específicos para qualificar o real grau
Mapa 8 - Terra Indígena Kapinawá 
de conservação destas "ilhas de vegetação" encontradas no interior das Terras Indígenas aqui citadas, é evidente que o grau de degradação desses ambientes é flagrantemente mais reduzido quando comparado às àreas circunvizinhas.

Ironicamente, exatamente por manter estas áreas conservadas que destoam de seu entorno degradado, as TIs estão sujeitas a invasões de não indígenas para exploração ilegal de recursos naturais (madeira, caça e outros) que têm nestes locais algumas de suas últimas fontes na região, o que ocasiona conflitos que nem sempre têm contado com apoio devido dos órgãos públicos responsáveis.

\section{Considerações finais}

Encerramos este texto fazendo um breve diálogo com Manuela Carneiro da Cunha. Em recente artigo categoricamente intitulado de "Povos da megadiversidade: o que mudou na política indigenista no último meio século" (Carneiro da Cunha, 2019), a autora enumera em poucas páginas a relevância dos povos indígenas (povos da megadiversidade) na manutenção da biodiversidade no mundo.

A autora retoma as mudanças na política de Estado para os povos indígenas no Brasil. Inicia sua narrativa com a enumeração do genocídio aos indígenas apresentada no Relatório Figueiredo e se pergunta o que mudou de lá para cá. Ao que responde que, na prática, pouca coisa mudou, "os índios continuam sendo mortos a bala e resistindo como podem à espoliação de suas terras”. Por outro lado, frisa como a teoria, e as leis, mudaram:

A ideia de "integração" deixou de ser sinônimo de assimilação. A missão do Estado não é mais entendida como sendo a de descaracterizar sociedades indígenas para trazê-las ao regaço da civilização, até porque elas só têm a perder nesse regaço. Integrar não é mais tentar eliminar diferenças, e sim articular com justiça as diferenças que existem. Assim, a Constituição de 1988, no caput do artigo 231, declara algo, isso sim, muito novo: "São reconhecidos aos índios sua organização social, costumes, línguas, crenças e tradições..." E no parágrafo $1^{\circ}$ do mesmo artigo, ao caracterizar o que são terras indígenas, inclui todas aquelas necessárias à reprodução física e cultural dos índios (Carneiro da Cunha, 2019, s.p.).

Essa virada permitiu que tanto a diversidade biológica quanto a sociodiversidade deixassem de ser vistas como um passivo e passassem a ser vistas como ativo, tal qual "enfatizou recentemente a Sociedade Brasileira para o Progresso da Ciência (SBPC). [...] Foi-se o tempo em que derrubar a mata significava fazer uma benfeitoria, em que massacrar índios era 'desinfestar os sertões”' (id.). A autora então explicita por que os povos indígenas são povos da megadiversidade:

Os conhecimentos e práticas dos povos indígenas têm sido reconhecidos em foros internacionais, como ficou patente no Painel Intergovernamental sobre Mudanças Climáticas (IPCC, na sigla em inglês), criado em 1988, e na Plataforma Intergovernamental sobre Biodiversidade e Serviços Ecossis- 
têmicos (IPBES, na sigla em inglês), de 2012. A arqueologia brasileira tem posto em evidência que o enriquecimento da cobertura e dos solos da floresta - as fertilíssimas "terras pretas" - é fruto das práticas de populações indígenas desde a era pré-colombiana até hoje. E sabe-se agora que na Amazônia foram domesticadas dezenas de plantas, entre as quais a batata-doce, a mandioca, o cará, a abóbora, o amendoim e o cacau. [...] Os povos indígenas e comunidades tradicionais são também provedores da diversidade das plantas agrícolas, a chamada agrobiodiversidade, fundamental para a segurança alimentar. A Revolução Verde do pós-guerra, que investiu nas variedades mais produtivas de cada espécie agrícola, teve grande sucesso no volume das colheitas, mas produziu danos colaterais. Um deles foi a perda maciça de variedades agrícolas, como as de arroz na Índia e de milho no México. [...]É por isso que no Alto Rio Negro há mais de 100 variedades de mandioca; nos caiapós, 56 variedades de batata-doce; nos canelas, 52 de favas; nos kawaiwetes, 27 de amendoim; nos wajãpis, 17 de algodão; nos baniuas, 78 de pimenta - sem falar na diversidade de espécies em cada roçado e quintal. Para os caiapós, bonito é um roçado com muita diversidade, pois os povos indígenas são mais do que selecionadores de variedades de uma mesma espécie. Eles são, de fato, colecionadores. (ibid)

Reafirmamos aqui a importância das Terras indígenas situadas na área do bioma Caatinga, uma vez que este papel das TIs como áreas protegidas da proteção da sociobiodiversidade tem sido muito evocado quando a referência são esforços de conservação nas regiões amazônicas ou mesmo do cerrado brasileiro. Não obstante a relevância destas áreas, pretendemos aqui destacar a ausência destes discursos quando o foco são os povos indígenas residentes na Região Nordeste do Brasil. Assim, estas narrativas (ou ausência das mesmas) subestimam o papel e a potencialidade de uma região onde vive uma parcela expressiva da população indígena no Brasil. E, a despeito da efetivação de seus direitos territoriais ainda estar muito aquém do necessário, ainda atuam de forma incisiva na proteção do que resta, muitas vezes em conflito com o próprio aparato estatal, incluindo-se aí o de conservação ambiental.

Recebido: 29/05/2019

Aprovado: 05/08/2019 


\section{Referências}

ALBUQUERQUE JR., Durval Muniz. A aridez das ideias: a questão ambiental do Nordeste em busca de práticas e discursos inovadores. In: SANTOS, Ana Paula dos; ALBUQUERQUE JR., Durval Muniz; BRAGA, Ricardo Augusto (Orgs.). O encolhimento das águas: o que se vê e o que se diz sobre crise hídrica e convivência com o semiárido. Campina Grande: Insa, 2018.

ANAí - Associação Nacional de Ação Indigenista. Carta Acordo. Salvador: Anaí, 2014.

ANAÍ - Associação Nacional de Ação Indigenista. Mapeamento da TI Entre Serras Pankararu - Produto 6. Salvador: Anaí, 2015.

ANDRADE, L. E. A. de; DANTAS, Marcelino S. O tempo e a terra: mapeamento do Território Kapinawá. Olinda: CCLF, 2017. Disponível em: https://1drv.ms/f/s!AoiZuLmnp27g_lukYvq1GwGqgcaQg. Acesso em: 12 jan. 2019.

ANDRADE, Lara E. A. de; DANTAS, Marcelino S.; NILSSON, Maurice T. Etnomapeamento da Terra Indígena Entre Serras Pankararu. Salvador: Anaí, 2016. Disponível em: http:// cggamgati.funai.gov.br/files/1714/8776/9858/Etnomapeamento_TI_Entre_Serras_ de_Pankararu.pdf. Acesso em: 12 jan. 2019.

APIB - Articulação dos Povos Indígenas do Brasil (APIB). Participação e protagonismo indígena - A experiência do projeto GATI em Terras Indígenas. Brasília: IEB, 2016.

ASA - Articulação do Semiárido Brasileiro. Semiárido. 2019. Disponível em: http://www. asabrasil.org.br/semiarido. Acesso em: 12 jan. 2019.

BENSUSAN, Nurit. Diversidade e unidade: um dilema constante - Uma breve história da ideia de conservar a natureza em áreas protegidas e seus dilemas. In: BENSUSAN, Nurit; PRATES, Ana Paula (Orgs.). A diversidade cabe na unidade? Áreas protegidas no Brasil. Brasília: IEB, 2014.

BRASIL. Ministério do Meio Ambiente - MMA. Caatinga. 2019. Disponível em: http:// www. mma.gov.br/biomas/caatinga. Acesso em: 12 jan. 2019.

BRASIL. Ministério do Meio Ambiente - MMA. Ibama. Monitoramento do Desmatamento dos Biomas Brasileiros por Satélite - PMDBBS 2010-2011 CAATINGA - Relatório técnico. Brasília: MMA, 2016.

CARNEIRO DA CUNHA, Manuela. Povos da Megadiversidade - O que mudou na política indigenista no último meio século. Revista Piauí, ed. 148, jan. 2019.

CLEMENT, Charles R.; DENEVAN, William M.; HECKENBERGER, Michael J.; JUNQUEIRA, André B.; NEVES, Eduardo G.; TEIXEIRA, Wenceslau G.; WOODS, William I. 2015. The domestication of Amazonia before European conquest. Proceedings of the Royal Society B: Biological Sciences, v. 282, n. 1812, p. 20150813. Disponível em: https://sta.rl.talis. com/items/9768E0F6-AFAF-FFA2-9AE0-6F78699E3859.html. Acesso em: 20 ago. 2019.

DANTAS, Beatriz; SAMPAIO, José Augusto; CARVALHO, Maria Rosário. Os Povos Indígenas no Nordeste Brasileiro: um esboço histórico. In: CUNHA, Manuela Carneiro da. História dos índios no Brasil. São Paulo: Companhia das Letras; Secretaria Municial de Cultura: FAPESP, 1992. p. 431-456.

DIEGUES, Antonio Carlos Sant'Ana. O mito moderno da natureza intocada. 4. ed. São Paulo: Hucitec, 2002.

DUDLEY, N. (Ed.). Guidelines for Applying Protected Area Management Categories. Gland, Switzerland: IUCN, 2008. Disponível em: https://www.iucn.org/pa_categories. Acesso em: 20 ago. 2019. 
FREIRE, Neison Cabral Ferreira et al. (Orgs.). Atlas das caatingas - O único bioma exclusivamente brasileiro. Recife: Fundação Joaquim Nabuco; Massangana, 2018.

FUNAI - Fundação Nacional do Indio. Situação Fundiária das Terras Indígenas. 2019. Disponível em: http://mapas2.funai.gov.br/portal_mapas/pdf/terra_indigena.pdf. Acesso em: 20 ago. 2019.

FUNDAÇÃO CULTURAL PALMARES. Quadro geral de Comunidades Remanescentes de Quilombos (CRQs). 2019. Disponível em: http://www.palmares.gov.br/wp-content/ uploads/2015/07/quadro-geral-02-08-2019.pdf. Acesso em: 20 ago. 2019.

GÓMEZ-POMPA, Arturo; KAUS, Andrea. Taming the wilderness myth. Bioscience, v. 42, n. 4, p. 271-279, 1992.

IBGE. Censo demográfico 2010: características gerais dos indígenas - resultados do universo. Rio de Janeiro. 2012. Disponível em: https://indigenas.ibge.gov.br/. Acesso em: 20 ago. 2019.

IBGE. Amazônia Legal - O que é. Disponível em: https://www.ibge.gov.br/ geociencias/ informacoes-ambientais/vegetacao/15819-amazonia-legal.html?=\&t=o-que-e. Acesso em: 05 jun. 2018.

IBGE. Censo Agro 2017 - Resultados preliminares. 2019. Disponível em: https:// censos. ibge.gov.br/agro/2017/templates/censo_agro/resultadosagro/pecuaria.html Acesso em: 05 jun. 2018.

ISA - Instituto Socioambiental. Programa Monitoramento de Áreas Protegidas. SisArp (Sistema de Áreas Protegidas). 2016. Disponível em: https://terrasindigenas.org.br/ pt-br/brasil. Acesso em: 05 jun. 2018.

LIMA, Ricardo da Cunha Correia; CAVALCANTE, Arnóbio de Mendonça Barreto; PEREZ-MARIN, Aldrin Martin. Desertificação e mudanças climáticas no semiárido brasileiro. Campina Grande: INSA-PB, 2011.

NOVA Cartografia Social dos Povos e Comunidades Tradicionais do Brasil. Coordenação do projeto: ALMEIDA, Alfredo Wagner Berno de; MARIN, Rosa Azevedo (coord.). Organização: CARVALHO, Franklin Plessmann de; VIANA, Greice Bezerra. Fundos de pasto: nosso jeito de viver no sertão - Oliveira dos Brejinhos e Brotas de Macaúbas - BA. Manaus: UEA Edições, 2012.

NOVA Cartografia Social dos Povos e Comunidades Tradicionais do Brasil. Comunidades dos pescadores e pescadoras artesanais - Mostrando sua cara, vez e voz, Submédio e Baixo São Francisco. Fascículo 4. Manaus: UEA Edições, 2007.

OLIVEIRA, João Pacheco (Org.). A viagem da volta: etnicidade, política e reelaboração cultural no nordeste indígena. Rio de Janeiro: Contra Capa, 1999.

POMPA, Cristina. Religião como tradução: missionários, Tupi e Tapuia no Brasil colonial. Tese [Doutorado em Antropologia] - Universidade Estadual de Campinas, Campinas, 2001.

RAMOS, Adriana. Políticas públicas para áreas protegidas no Brasil. In: BENSUSAN, Nurit; PRATES, Ana Paula (Orgs.). A diversidade cabe na unidade? Áreas protegidas no Brasil. Brasília: IEB, 2014.

RICARDO, Fany (Org.). Terras Indígenas \& Unidades de Conservação da natureza: o desafio das sobreposições. São Paulo: Instituto Socioambiental, 2004.

SANTOS JÚNIOR, Avelar; DANTAS, Marcelino S.; NILSSON, Maurice T. Etnomapeamento da Terra Indígena Caiçara/Ilha de São Pedro do povo Xokó. Salvador: Anaí, 2016. 